\title{
PROCEDIMENTOS METODOLÓGICOS PARA AVALIAÇÃO DA ARBORIZAÇÃO URBANA NA CIDADE DE SÃO PAULO
}

\author{
METHODOLOGICAL PROCEDURES FOR URBAN ARBORIZATION AVALIATION \\ IN SÃO PAULO CITY
}

Bruno Madeira Cruz*

\begin{abstract}
RESUMO
Este artigo apresenta uma metodologia para quantificação da existência de vegetação na cidade de São Paulo através do mapeamento dos dosséis arbóreos mais significativos na área de estudo, demonstrando sua utilização como ferramenta de análise da paisagem urbana. Os recentes avanços na área técnica de Sistemas de Informações Geográficas (SIG) possibilitaram um aprimoramento significativo da metodologia original.

Palavras-chave: Arborização. SIG. Paisagem.
\end{abstract}

\section{ABSTRACT}

This paper presents a methodology for urban vegetal quantification in São Paulo city, through mapping the most significant tree canopies inside the studied area and demonstrating its utilization as an urban landscape analysis tool. Recent upgrade in GIS (geographic information system) software allowed substancial advances in the original methodology.

Keywords: Arborization. GIS. Landscape.

\section{INTRODUÇÃO}

A importância da vegetação nas grandes cidades tropicais vem ganhando crescente espaço no debate acadêmico. Encontram-se lado a lado, nas zonas urbanas, áreas ocupadas por algum tipo de floresta urbana e outras de extrema aridez quanto à existência de vegetação. De acordo com Grey (1978), florestas urbanas são todas as massas vegetacionais lenhosas dentro de ambientes habitados por seres humanos, desde pequenas vilas até megalópoles. Não incluem apenas árvores dentro dos limites urbanos, mas também as que de alguma forma interferem nos mesmos - como reservas próximas onde podem ser encontradas residências esparsas.

\footnotetext{
* Geógrafo pela Faculdade de Filosofia, Letras e Ciências Humanas da Universidade de São Paulo (FFLCH-USP), mestre em Paisagem e Ambiente pela Faculdade de Arquitetura e Urbanismo da Universidade de São Paulo (FAUUSP), pesquisador do Laboratório Quadro do Paisagismo no Brasil (LABQUAPÁ) da FAUUSP.

brunomadeiracruz@yahoo.com.br
} 
De acordo com este conceito, florestas urbanas e matas nativas podem ser igualmente complexas, embora isto esteja limitado ao exemplo oferecido. Dentro do sistema de espaços livres paulistanos, por exemplo, estão dispostas em parques, praças, quintais, jardins e acompanhando o sistema viário - não logrando atingir o mesmo grau de complexidade da serra do Mar mesmo quando contínuas e remanescentes. A vegetação pode ser encontrada da seguinte forma:

a) manchas complexas: massas vegetais volumosas, normalmente remanescentes, ou, ainda, trechos integrais de matas nativas. No caso paulistano, podem ser encontradas em alguns parques e reservas florestais. As manchas complexas podem ser divididas em:

- matrizes: manchas de grande porte, constituídas por alqueires inteiros e contínuos de mata nativa, normalmente representados por reservas, áreas de proteção permanente e estações experimentais; contêm ecossistemas completos; possuem área suficientemente grande para abrigar cadeias completas de vida animal e espécies vegetais primárias, secundárias e terciárias; espécies primárias (ou pioneiras) são as primeiras a se desenvolverem em seus respectivos ecossistemas, como a embaúba e o guapuruvu na mata atlântica; as secundárias são aquelas que crescem sob a sombra de espécies pioneiras, como o palmito e o pau-brasil; as espécies vegetais terciárias (ou clímax) surgem somente após as secundárias, normalmente com madeiras mais valiosas, como o mogno; no Estado de São Paulo, apenas a serra da Cantareira e a do Mar enquadram-se nesta definição.

- manchas remanescentes: são semelhantes às matrizes, mas possuem área menor, de médio porte, e não desenvolvem ecossistemas completos, já que áreas menores não possibilitam cadeias inteiras de vida animal; são incapazes de cumprir funções retroalimentativas da flora, havendo menores possibilidades para o desenvolvimento de espécies vegetais secundárias e terciárias; normalmente, segundo Forman (1996), são fragmentos ecológicos - áreas homogêneas que diferem dos arredores - plantados pelo homem na forma de parques, com espécies nativas e introduzidas ou fragmentos que resistiram ao desmatamento (no caso paulistano, destacam-se os parques Previdência e Alfredo Volpi).

b) corredores: para Forman et al. (1996), a perda e o isolamento de hábitats são constantes do mundo contemporâneo. Tal perda ocorre através de várias dinâmicas: fragmentação (quebra de um grande patch em vários, menores e dispersos), dissecção (divisão de um patch em dois menores, unidos por um corredor), perfuração (abertura de clareiras em um hábitat até então intacto), encolhimento (redução do tamanho pela corrosão das bordas) e, finalmente, o desaparecimento completo. Frente à situação de perda e isolamento, diversos cientistas chamaram atenção para a necessidade de providenciar conectividade entre estes hábitats, 
especialmente na forma de corredores contínuos, semicontínuos ou no estilo stepping stones para a vida selvagem (figura 1).

Desta forma, enquanto stepping stones seriam pequenos fragmentos próximos uns aos outros, os corredores configurariam uma massa vegetacional alongada unindo dois fragmentos, permitindo, assim, a circulação da fauna entre eles. Embora sua eficácia ainda esteja sujeita a debates e, vez por outra, possam funcionar como "barreiras" ou "filtros" para algumas espécies, efeitos predominantemente positivos vêm sendo observados. A efetividade de um corredor contínuo e dos stepping stones está ligada à espessura e continuidade, no primeiro caso, e proximidade entre os stepping stones no segundo (figuras 2 e 3 ).

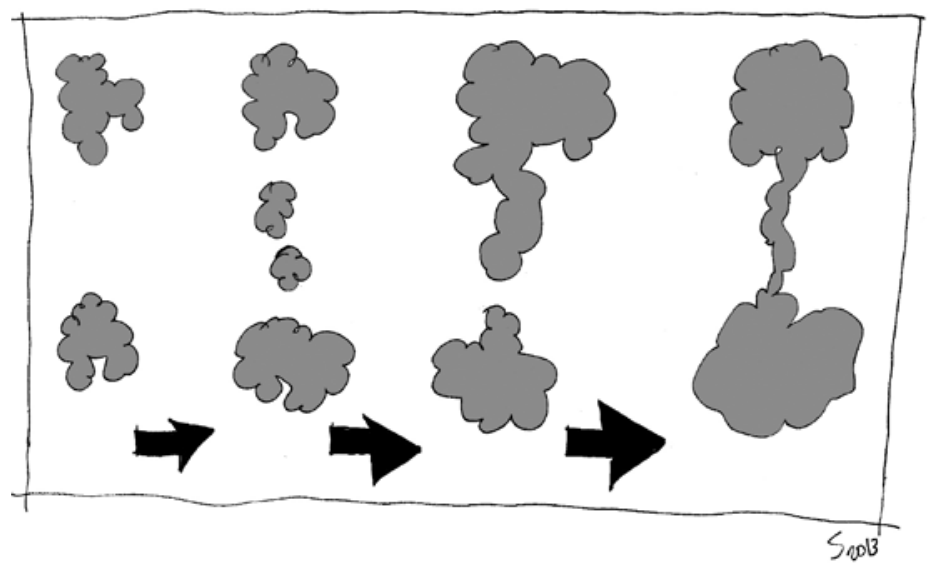

Figura 1 Efetividade de um corredor.

Fonte: Desenho de Silvio Soares Macedo, 2013. Adaptado de Forman et. al (1996, p. 36).

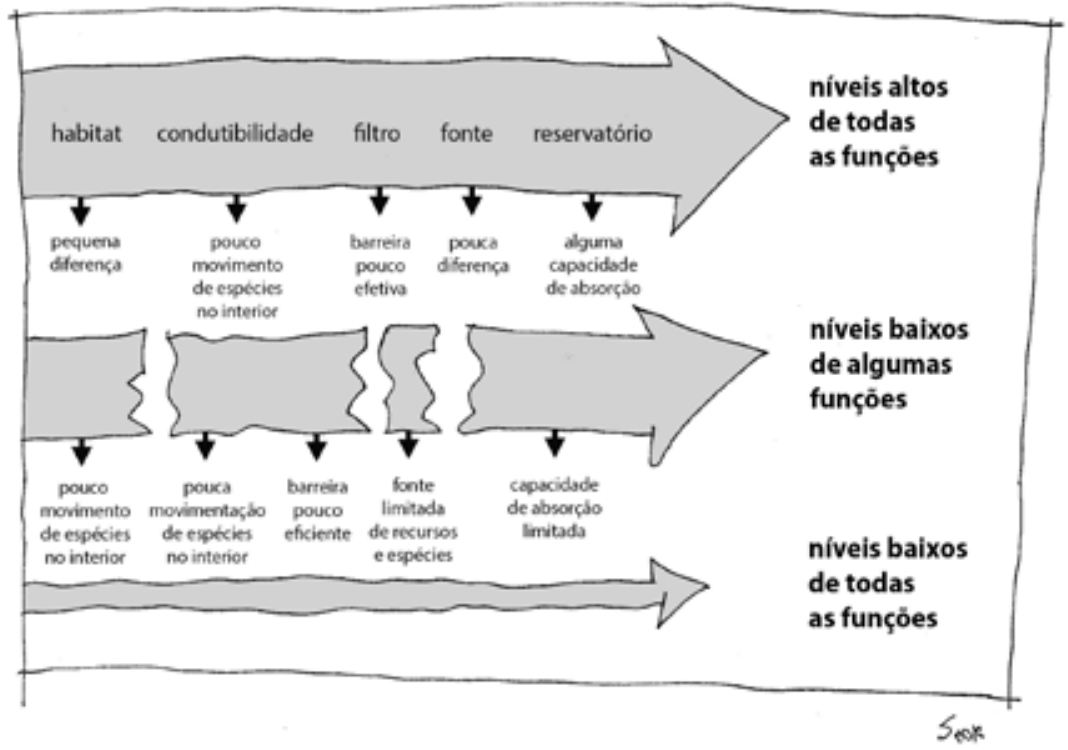

Figura 2 Hábitats isolados, stepping stones, corredores semicontínuos e contínuos. Fonte: Desenho de Silvio Soares Macedo, 2013. Adaptado de Forman et. al (1996, p. 36). 

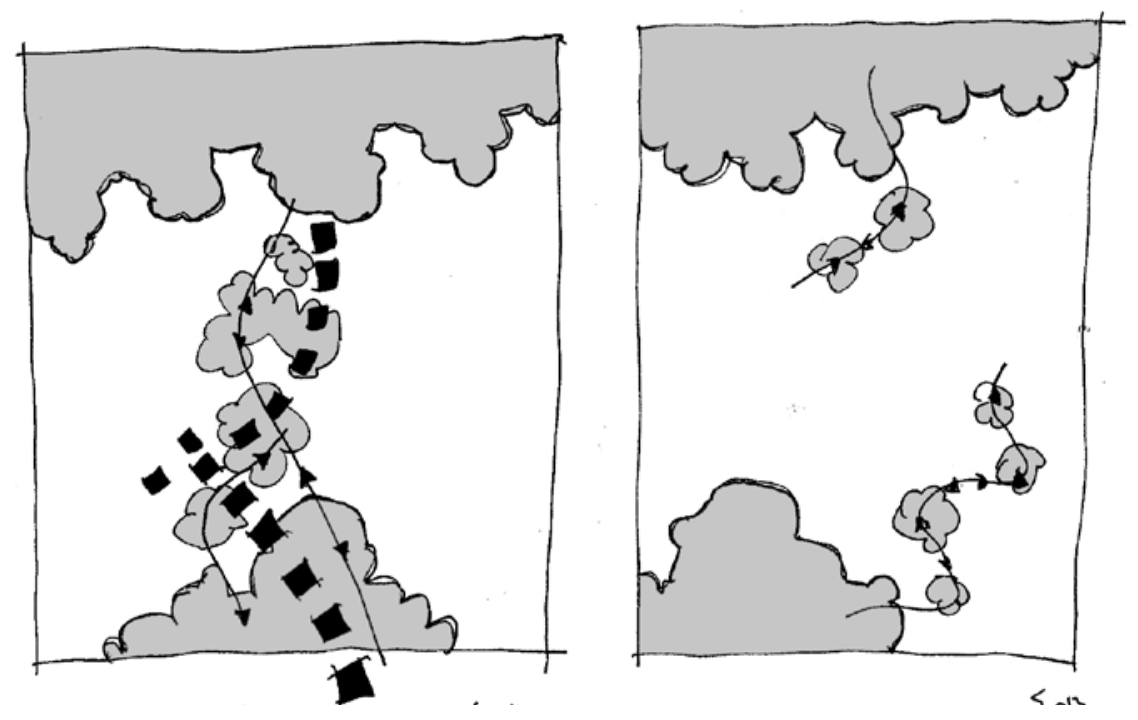

Figura 3 Efetividade dos stepping stones.

Fonte: Desenho de Silvio Soares Macedo, 2013. Adaptado de Forman et. al (1996).

Os corredores, além dos três tipos citados, ainda podem ser subdivididos em dois grandes grupos:

- complexos: constituídos de remanescentes de mata nativa;

- simples: constituídos de vegetação urbana comum, com baixa ou nenhuma heterogeneidade de indivíduos. No caso paulistano, seus fragmentos são identificados nas represas Billings e Guarapiranga e bordas do parque do Estado.

c) vegetação cotidiana (indivíduos e manchas isolados): quando há o simples predomínio visual da arborização, com uma pequena diversidade animal, em especial de aves e insetos; como exemplo, os bairros Jardins e Chácara Flora.

Forman et al. (1996) demonstram como a área dos patches interfere em sua biodiversidade. Para tanto, divide tais bolsões em borda e interior, cada qual com suas espécies próprias. A divisão de um fragmento em duas metades acarreta um ligeiro aumento (13\%) de espécies de borda, de quantidade de indivíduos e, também, uma perda substancial de espécies e indivíduos interiores (70\%), como visto na figura 4.

Desta forma, um grande fragmento é capaz de abrigar um número muito maior de espécies e indivíduos do que em três menores de área equivalente juntos. É também a única estrutura de uma paisagem capaz de proteger grandes aquíferos. Os riscos de extinção também são maiores em pequenos resíduos, pois estão diretamente relacionados a populações rarefeitas, como visto na figura 5 .

Entretanto, como demonstrado na figura 6, pequenos fragmentos podem oferecer vantagens. Especialmente quando posicionados próximos uns aos outros são capazes de desempenhar, para espécies em movimento, a função de stepping stones (assemeIhando-se, sob esta ótica, aos corredores) ou simular a função de um único fragmento de grande porte. 


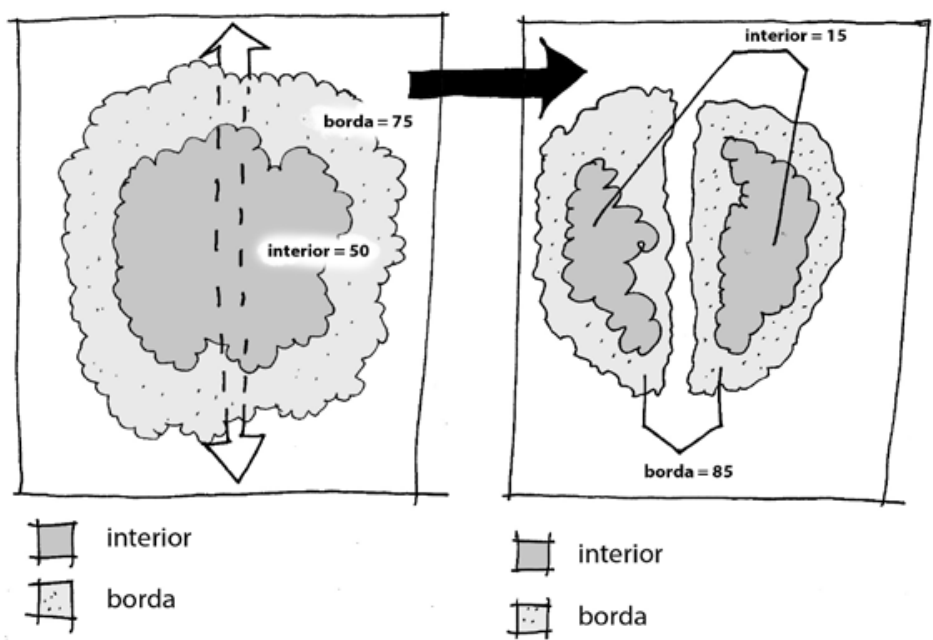

Figura 4 Fragmentos grandes e pequenos.

Fonte: Desenho de Silvio Soares Macedo, 2013. Adaptado de Forman et. al (1996, p. 20).
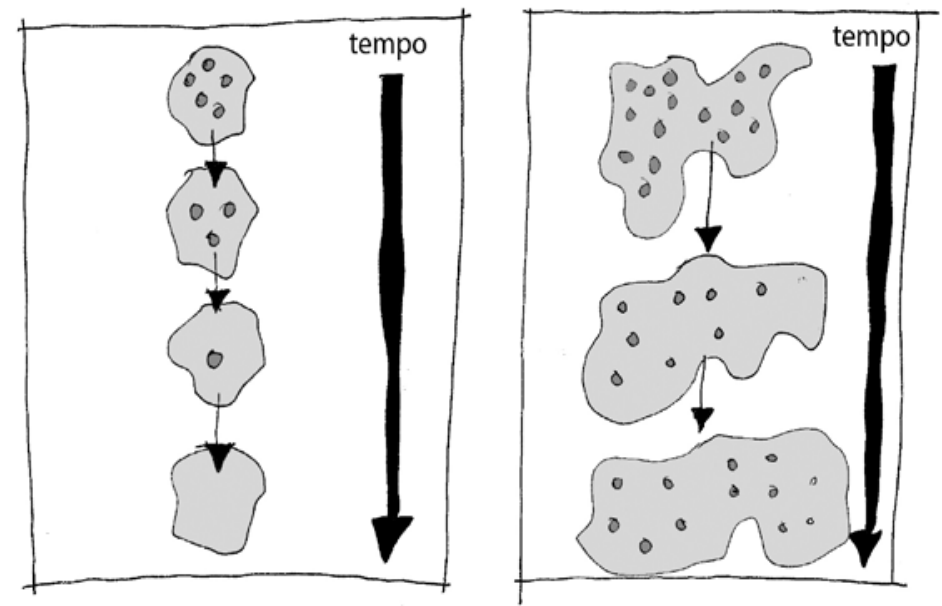

Fonte: Figura 5 Maior risco de extinção quanto menor a área do fragmento ao longo do tempo.

Desenho de Silvio Soares Macedo, 2013. Adaptado de Forman et. al (1996, p. 20).
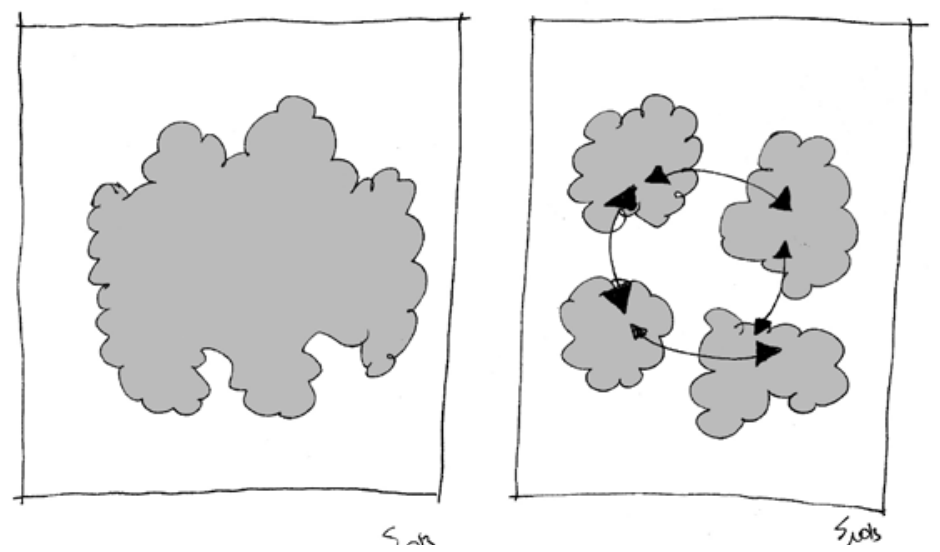

Figura 6 Fragmentos grandes e pequenos.

Fonte: Desenho de Silvio Soares Macedo, 2013. Adaptado de Forman et. al (1996, p. 22). 
Grey (1978) afirma que os benefícios da floresta urbana podem ser divididos basicamente em quatro grupos: melhora climática; usos de engenharia; usos arquitetônicos; usos estéticos.

A melhora climática costuma destacar-se perante os demais quanto à atenção acadêmica recebida. Normalmente, se pensa a arborização urbana unicamente como forma de aliviar os indesejáveis e deletérios efeitos das "ilhas de calor", termo que designa variações de temperatura seguindo isotermas concêntricas, que sugerem o formato de "ilhas", com pontos máximos de calor no centro, coincidindo com zonas mais densamente construídas, normalmente, nos centros urbanos (VOOGT, 2004). De fato, as árvores são capazes de interagir com a radiação solar, temperatura, movimentação e umidade do ar, gerando zonas de conforto térmico.

De acordo com Federer (1971), cidades tendem a ser de $0,5^{\circ} \mathrm{C}$ a $1,5^{\circ} \mathrm{C}$ mais quentes em relação ao campo que as rodeia. Esta diferença pode ser desejável em um inverno rigoroso, mas, no verão, é certamente causa de grande desconforto, especialmente sendo de $28^{\circ} \mathrm{C}$ a temperatura média máxima do mês de fevereiro em São Paulo, de acordo com o Instituto Nacional de Meteorologia (INMET), séries históricas de 1961 a 1990.

Os graus a mais em questão ocorrem, em grande parte, graças ao déficit de vegetação das cidades, comprometendo a absorção solar e o resfriamento do ar via evapotranspiração. Da radiação solar que penetra a atmosfera, aproximadamente metade atinge a superfície terrestre e é absorvida ao longo do dia pelo asfalto, concreto, aço, vidro, por telhas e outros componentes urbanos. Todos estes materiais são maus isolantes térmicos, ganhando mas também perdendo calor mais rapidamente que o solo e a vegetação. Desta forma, acaba havendo diferenças consideráveis de temperatura entre ambos os tipos de superfícies e o ar em torno delas.

As árvores, os arbustos e gramados amenizam de diversas formas o efeito do calor urbano. As árvores interceptam, refletem, absorvem e, durante o inverno, transmitem radiação solar, perdendo calor para o ar mais frio (GREY, 1978). A eficácia do controle climático está muito ligada à espécie utilizada, já que densidade da folhagem, formato dos galhos e das folhas são fatores importantes no processo de resfriamento. Como exemplo, espécies decíduas são bastante eficientes, por interceptar a radiação e reduzir a temperatura durante o verão. No inverno, a queda das folhas permite a passagem dos raios de sol com mais facilidade (GREY, 1978). Yázigi (2000) admite a necessidade de uma faixa de cobertura vegetal de $30 \%$ de uma determinada área urbana para assegurar o balanceamento térmico. Também afirma que copas ralas interceptam de $60 \%$ a $80 \%$ da radiação solar, enquanto as densas podem chegar a $98 \%$.

A evapotranspiração dos vegetais também reduz o ar quente nos dias mais tórridos. Evapotranspiração é a evaporação da água contida no solo, nas copas e nos corpos d'água para a atmosfera. No caso, o vapor sai dos estômatos (figura 7) das plantas, poros encontrados nas folhas para trocas gasosas com o exterior, e desloca o calor latente do ar (responsável pela maior evaporação da água na superfície dos vegetais), em um fenômeno físico conhecido como evaporative cooling. 


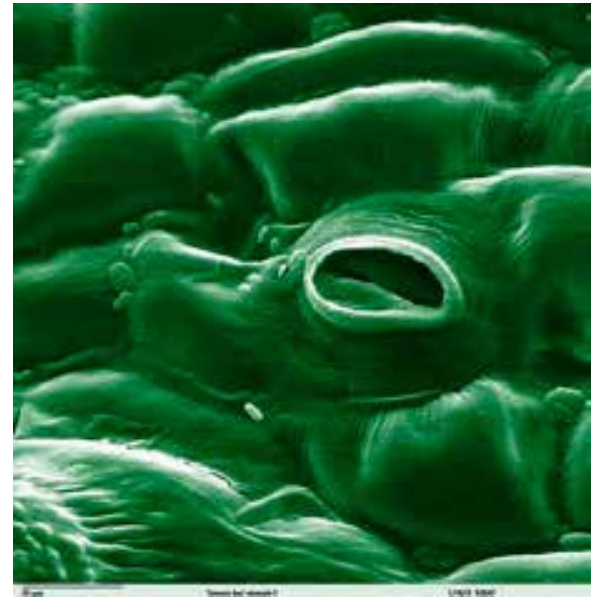

Figura 7 Estômato de folha de tomate.

Disponível em: <http://en.wikipedia.org/wiki/Stoma>

Acesso em: 2011.

Além da evapotranspiração, a simples presença de uma copa vegetal reduz a temperatura média do ar e do asfalto. Taha et al. (1988) demonstram que, nos subúrbios de Sacramento (California/EUA), a temperatura média do ar sob a folhagem arbórea era de $1,7^{\circ} \mathrm{C}$ a $3,3^{\circ} \mathrm{C}$ menor quando comparada a regiões sem árvores. Em Miami (Florida/EUA), a redução da temperatura média do ar sob as árvores era de $3,6^{\circ} \mathrm{C}$ durante o verão (PARKER, 1989). Akbari et al. (1992) demonstraram que, em Sacramento (California/EUA) e Phoenix (Arizona/EUA), o aumento de 25\% no número de árvores em uma região de casas - o que corresponde a três árvores por casa - pode reduzir, no verão, em $3,3-5,6^{\circ} \mathrm{C}$ a temperatura média do ar. Como demonstra a figura 8 , a influência do sombreamento sobre a temperatura média do solo revela-se ainda mais impressionante. De acordo com Laurie (1983), o concreto exposto ao sol é $10^{\circ} \mathrm{C}$ mais quente que o concreto à sombra de uma árvore de copa densa, $30^{\circ} \mathrm{C}$ mais quente que grama à sombra.

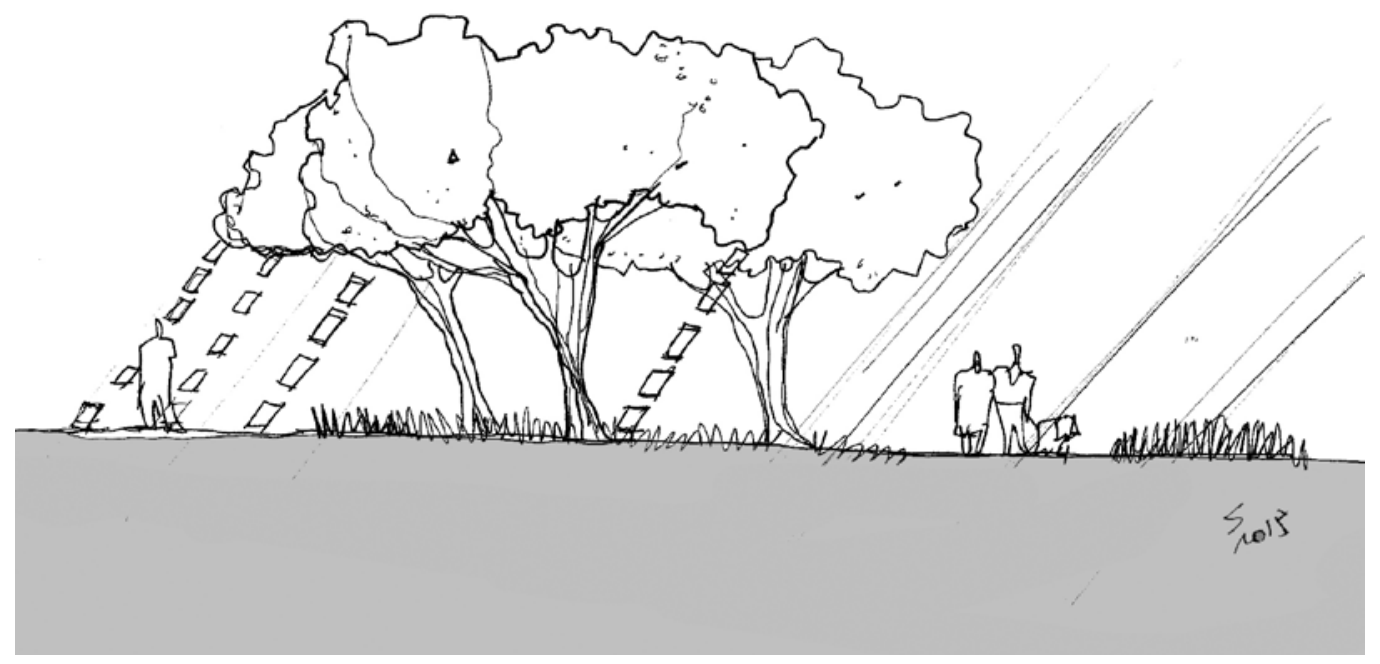

Figura 8 Temperatura de diferentes superfícies sob a sombra e sem cobertura arbórea. Fonte: Desenho de Silvio Soares Macedo, 2013. Adaptado de Laurie (1983). 
Para São Paulo, Shinzato (2009) encontrou uma diferença média de $1,5^{\circ} \mathrm{C}$ e $23^{\circ} \mathrm{C}$ entre a temperatura média do ar e do solo, respectivamente, nas áreas arborizadas e ruas adjacentes. Entretanto, o efeito da vegetação mostrou-se local, não transcendendo muito os limites das "áreas verdes". A tabela 1 demonstra como diferentes espécies de árvores brasileiras são capazes de alterar o microclima urbano:

\begin{tabular}{c|c|c|c|c|c}
\hline Espécies & Copa & Folhas & Folhagem & $\begin{array}{c}\text { Diferença na } \\
\text { temperatura } \\
\text { (inverno) }\end{array}$ & $\begin{array}{c}\text { Diferença na } \\
\text { temperatura } \\
\text { (verão) }\end{array}$ \\
\hline Extremosa & Permeável & $\begin{array}{c}\text { Verde-claras, } \\
\text { lisas }\end{array}$ & Caducifólia & $1^{\circ} \mathrm{C}$ & $4,5^{\circ} \mathrm{C}$ \\
\hline Sibipiruna & Permeável & $\begin{array}{c}\text { Verde- } \\
\text { escuras, lisas }\end{array}$ & Caducifólia & $1^{\circ} \mathrm{C}$ & $9^{\circ} \mathrm{C}$ \\
\hline Cinamomo & Permeável & $\begin{array}{c}\text { Verde- } \\
\text { escuras, lisas }\end{array}$ & Caducifólia & $3,5^{\circ} \mathrm{C}$ & $4,5^{\circ} \mathrm{C}$ \\
\hline
\end{tabular}

Tabela 1 Diferenças de temperatura sobre e sob a copa de algumas árvores brasileiras. Fonte: PREAMBE, 2001.

Manter a temperatura e a umidade relativa do ar em um determinado patamar é vital para o bem-estar dos pedestres em uma cidade e, como visto, as árvores possuem um papel essencial em ambientes urbanos como o paulistano para manter a temperatura entre $23^{\circ} \mathrm{C}$ e $25^{\circ} \mathrm{C}$, o recomendado pela Norma Brasileira 6401, de 1980 (NBR 6401), da Associação Brasileira de Normas Ténicas (ABNT). A figura 9 apresenta o diagrama de conforto térmico para pessoas em atividades sedentárias em um contexto de umidade relativa do ar entre $40 \%$ e $60 \%$, de acordo com a ANSI/ASHRAE Standard 55.

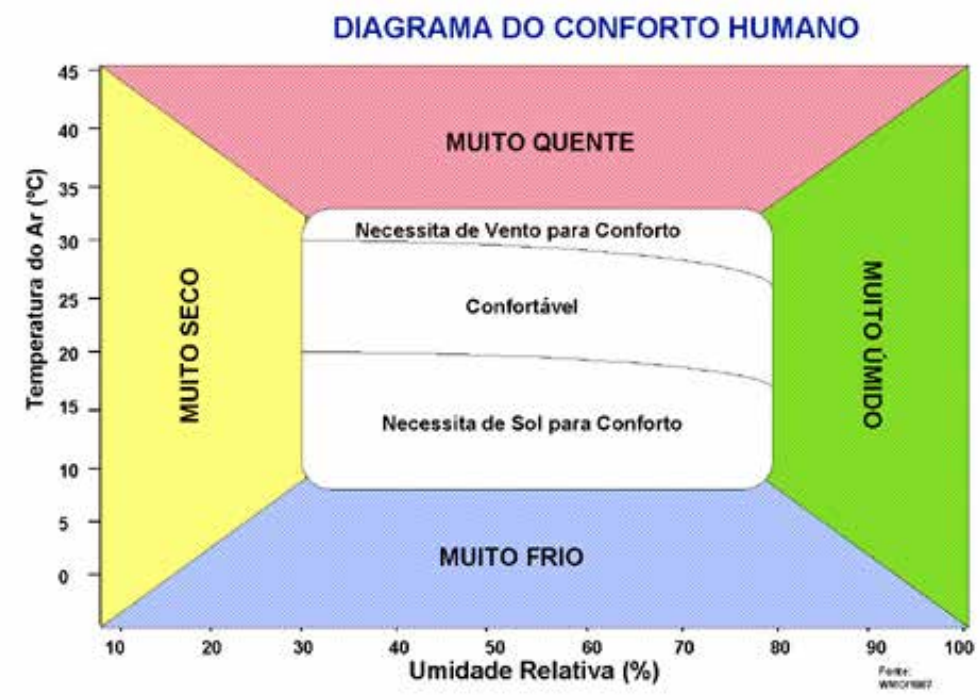

Figura 9 Diagrama do conforto humano.

Fonte: INMET/WMO. Disponível em: <http://www.inmet.gov.br/html/clima/conforto_term/>.

Acesso em: 10 ago. 2010. 


\section{FUNÇÕES ESTÉTICAS E ARQUITETÔNICAS DA ARBORIZAÇÃO}

O uso da vegetação altera as percepções visuais no ambiente. Sendo elemento estruturador da paisagem, a vegetação caracteriza as formas e cores da cidade, compõe o desenho urbano através da delimitação e caracterização de espaços livres e funciona como ponto de referência dentro da identidade local (figura 10).

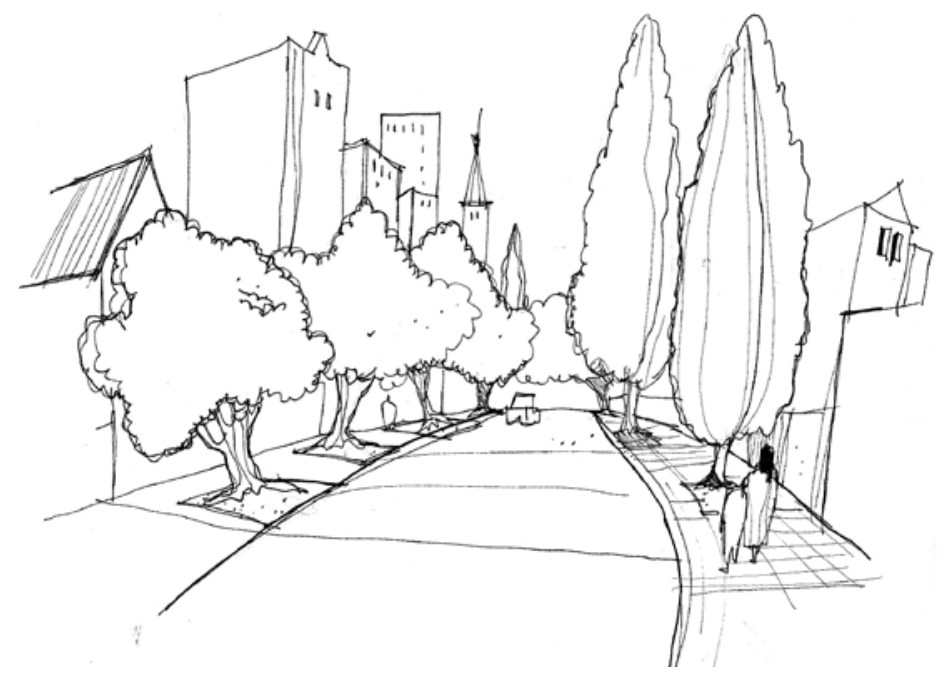

Figura 10 Paisagem delimitada apenas por vegetação.

Fonte: Desenho de Silvio Soares Macedo, 2013.

A vegetação tem o poder de criar planos de percepção através da organização do espaço (figura 11), ou, simplesmente, de formar uma cobertura vegetal aconchegante sob suas copas, sem influenciar o perfil das edificações (figura 12).

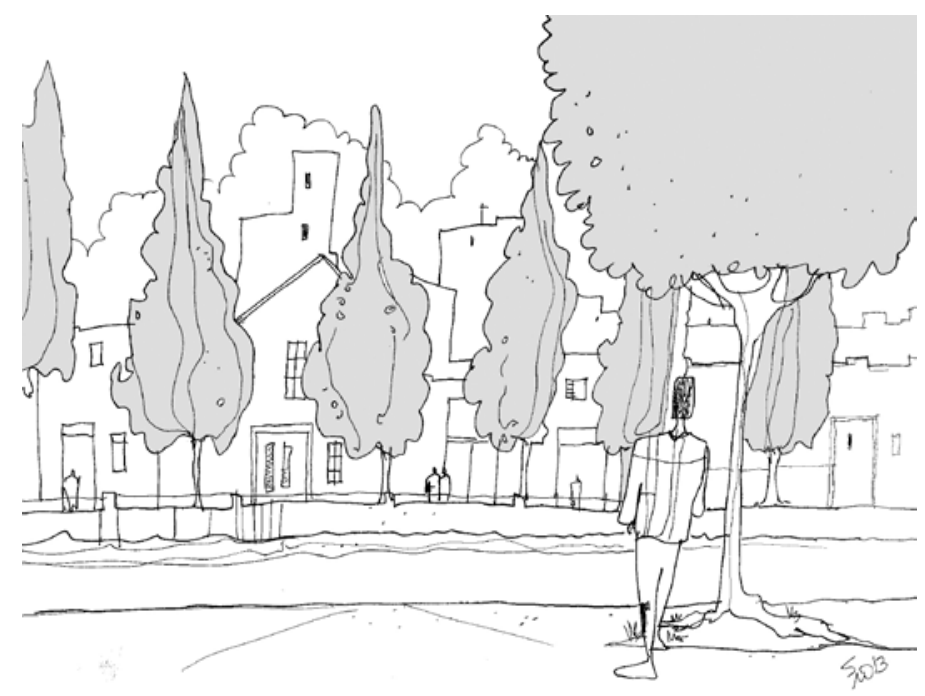

Figura 11 Vegetação organizando o espaço urbano. Fonte: Desenho de Silvio Soares Macedo, 2013. 


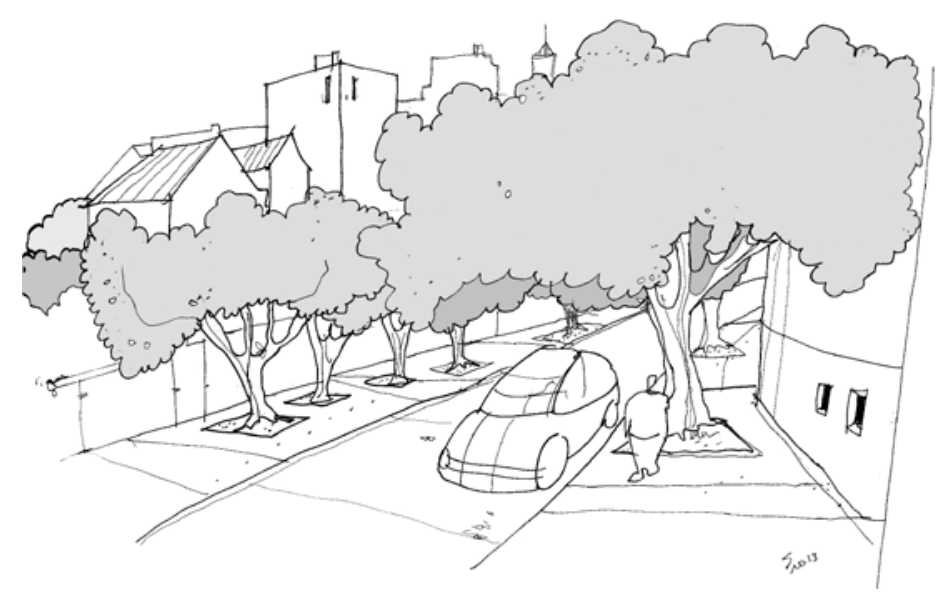

Figura 12 Vegetação formando cobertura sem influência das edificações.

Fonte: Desenho de Silvio Soares Macedo, 2013.

Também desempenha uma série de funções estéticas e arquitetônicas no espaço livre urbano. Para os usuários dos passeios, a mais relevante é a capacidade de ampliar a percepção do espaço das ruas, alterada pela existência de muros em torno das residências (figuras 13 e 14).

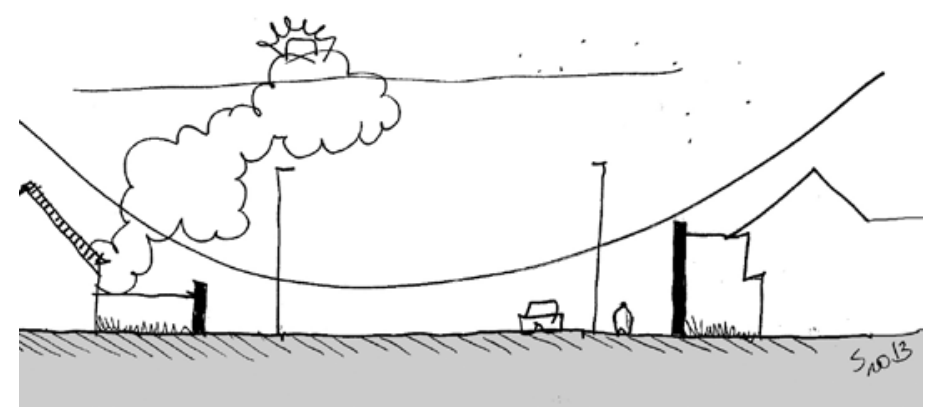

Figura 13 Muros estreitam o espaço da rua.

Fonte: Desenho de Silvio Soares Macedo, 2013. Adaptado de Mascaró (2010, p. 32).

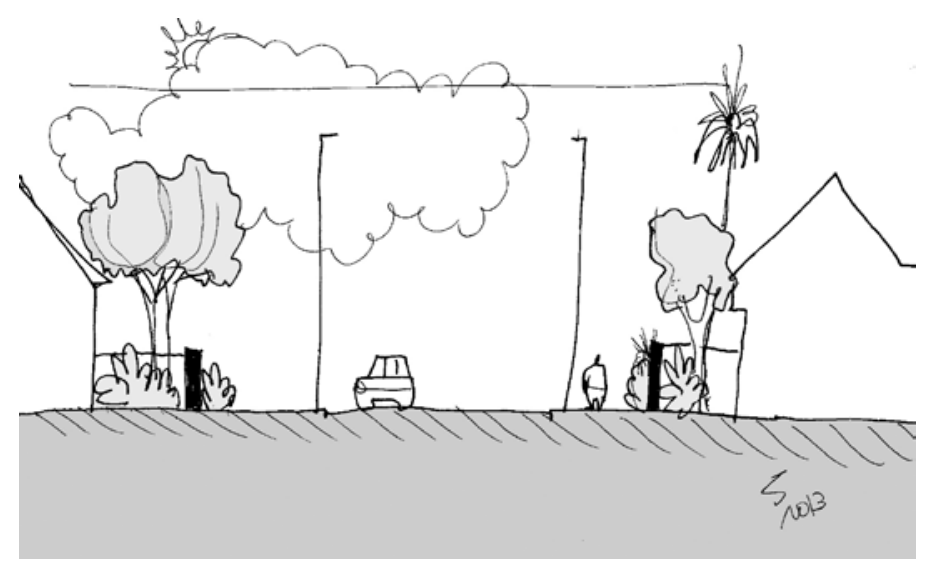

Figura 14 Vegetação ampliando a percepção básica do espaço da rua.

Fonte: Desenho de Silvio Soares Macedo, 2013. 
O uso de palmeiras enfileiradas pode ressaltar a perspectiva e sugerir imponência aos espaços, mas não contribui com a ambiência. Entretanto, árvores com copas amplas, usadas em igual situação, pouco contribuem com a perspectiva, embora aumentem o sombreamento (figuras 15 e 16).

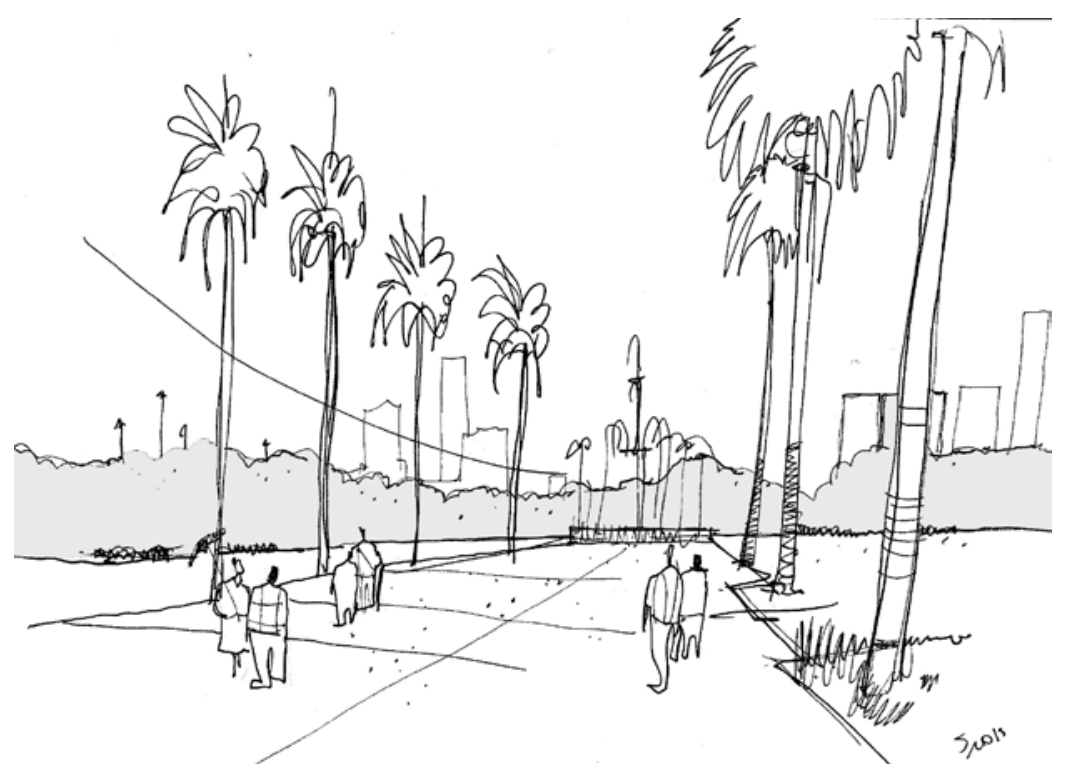

Figura $15 \bigcirc$ recando de árvores copadas nunca dará o efeito de perspectiva que a colunata de palmeiras possibilita.

Fonte: Desenho de Silvio Soares Macedo, 2013.

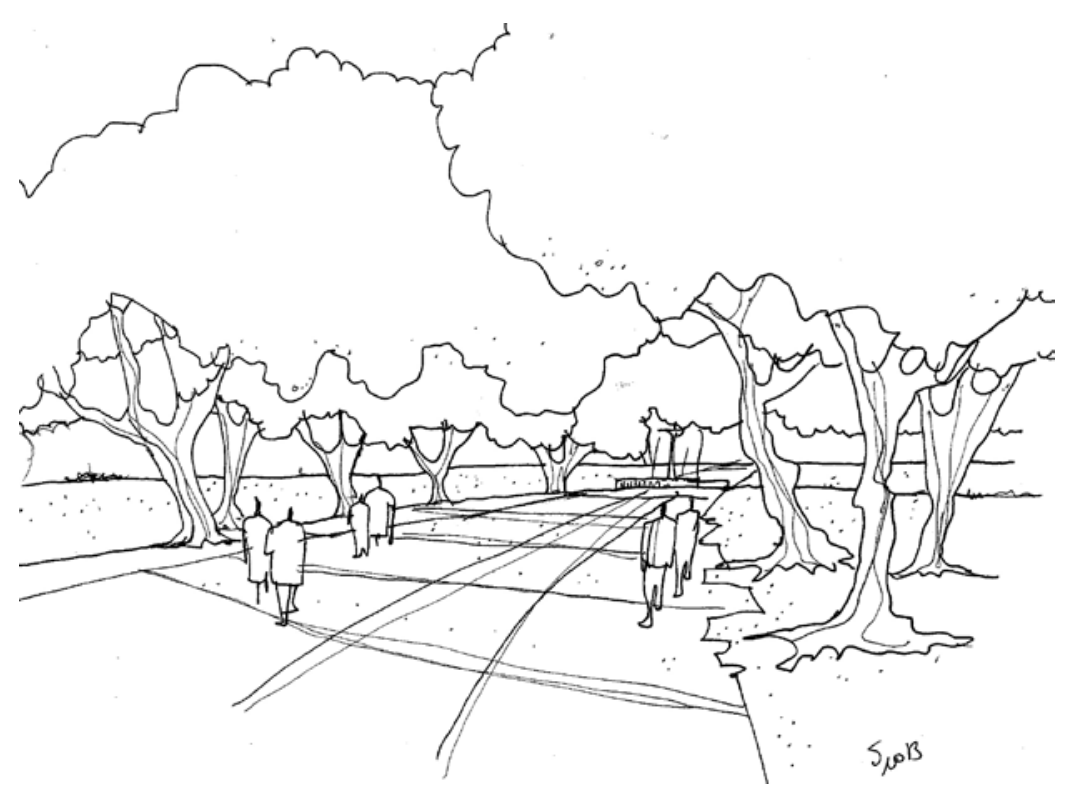

Figura 16 Copas minimizam a perspectiva, mas aumentam o sombreamento.

Fonte: Desenho de Silvio Soares Macedo, 2013. Adaptado de Mascaró (2010, p. 33).

Os maciços arbóreos revelam-se mais impactantes que indivíduos isolados, funcionando também como barreiras ambientais, proteção para pedestres em relação aos 
veículos do leito carroçável, definidores do espaço ou tendo, simplesmente, funções estéticas. Sendo heterogêneos, podem ser organizados para permitir a ventilação e diferentes níveis de insolação ao longo do ano, misturando espécies caducifólias e perenes (figura 17). Sendo homogêneos, o potencial paisagístico amplia-se ao ressaltar no espaço formas e cores predominantes daquela espécie (figura 18).

Os maciços homogêneos, durante o inverno, mantêm toda sua folhagem ou a perdem completamente. $O$ último caso permite a passagem dos raios do sol com mais facilidade, sendo ideal para invernos frios. Já os maciços heterogêneos criam paisagens diversificadas quanto aos dosséis arbóreos (figuras 19 e 20). A tabela 2 demonstra a transmitância luminosa no inverno e no verão para diferentes espécies utilizadas na arborização urbana.

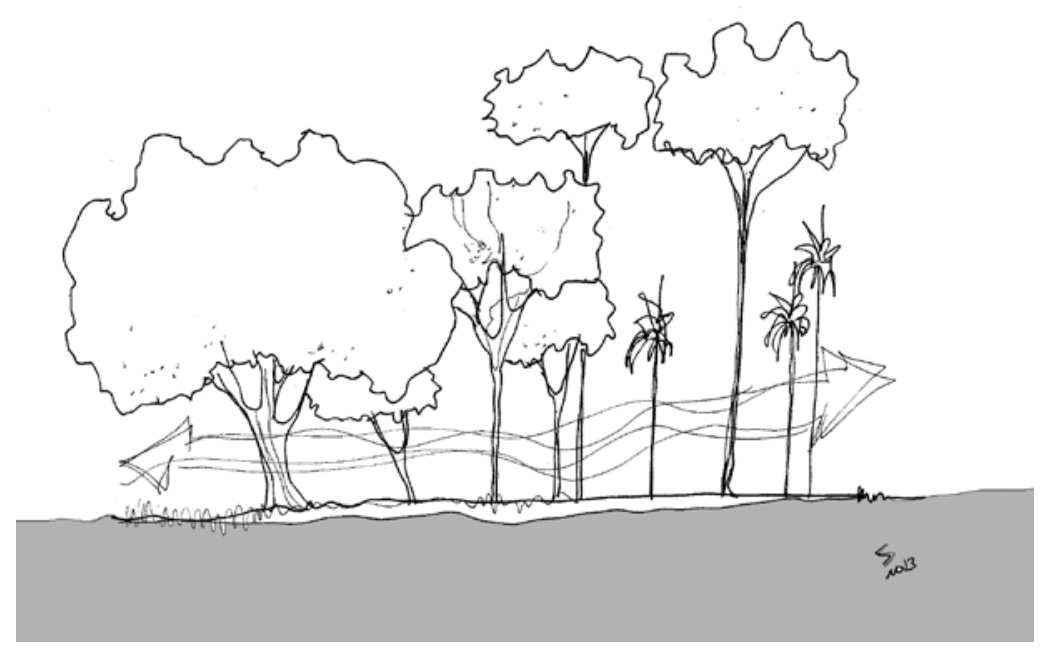

Figura 17 Um conjunto de árvores, plantadas de um modo esparço, permite uma boa circulação de ar. Fonte: Desenho de Silvio Soares Macedo, 2013. Adaptado de Mascaró (2010, p. 36).

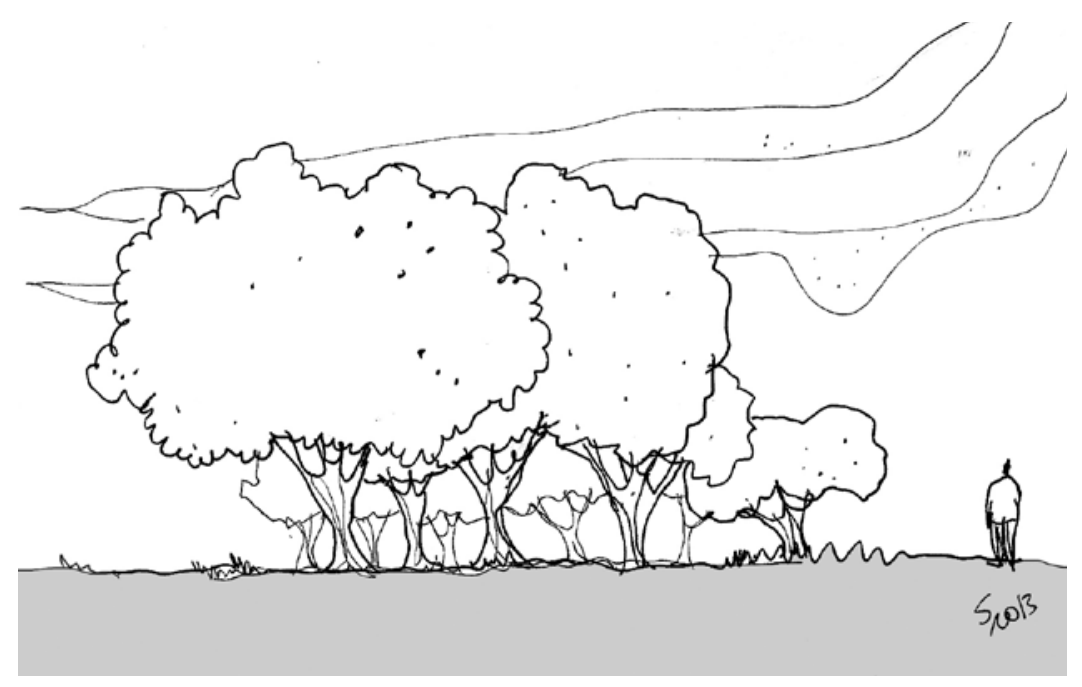

Figura 18 Maciço homogêneo enfatiza o paisagismo.

Fonte: Desenho de Silvio Soares Macedo, 2013. Adaptado de Mascaró (2010, p. 36). 


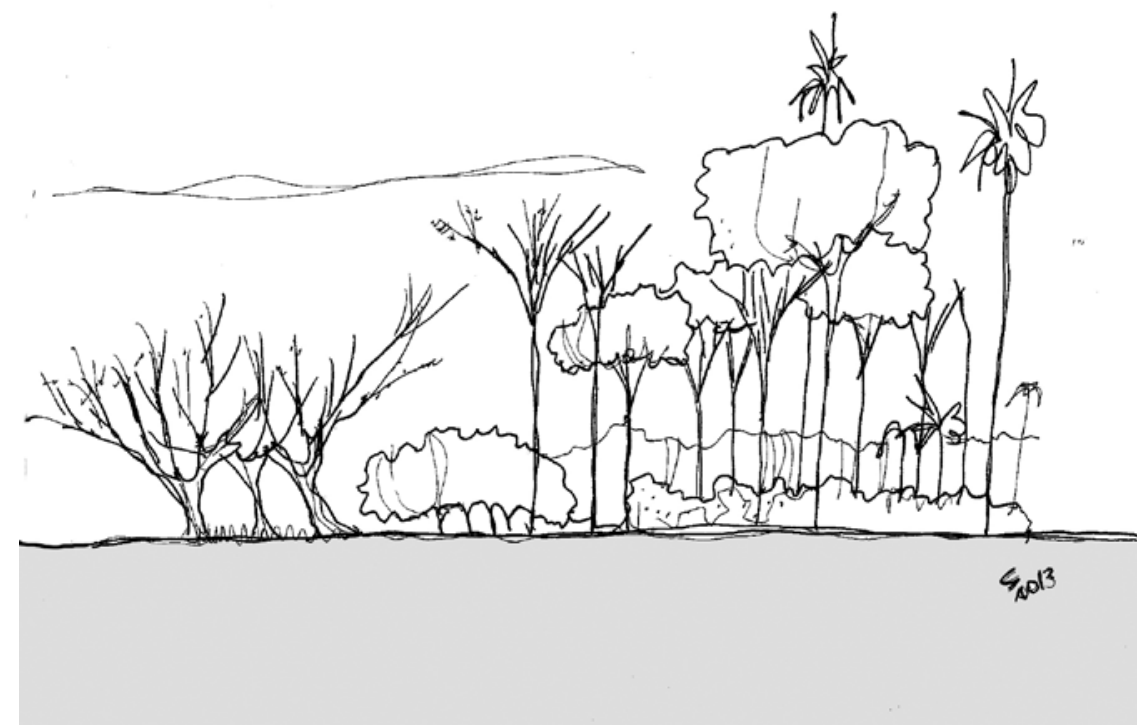

Figura 19 Maciço heterogêneo no inverno.

Fonte: Desenho de Silvio Soares Macedo, 2013.

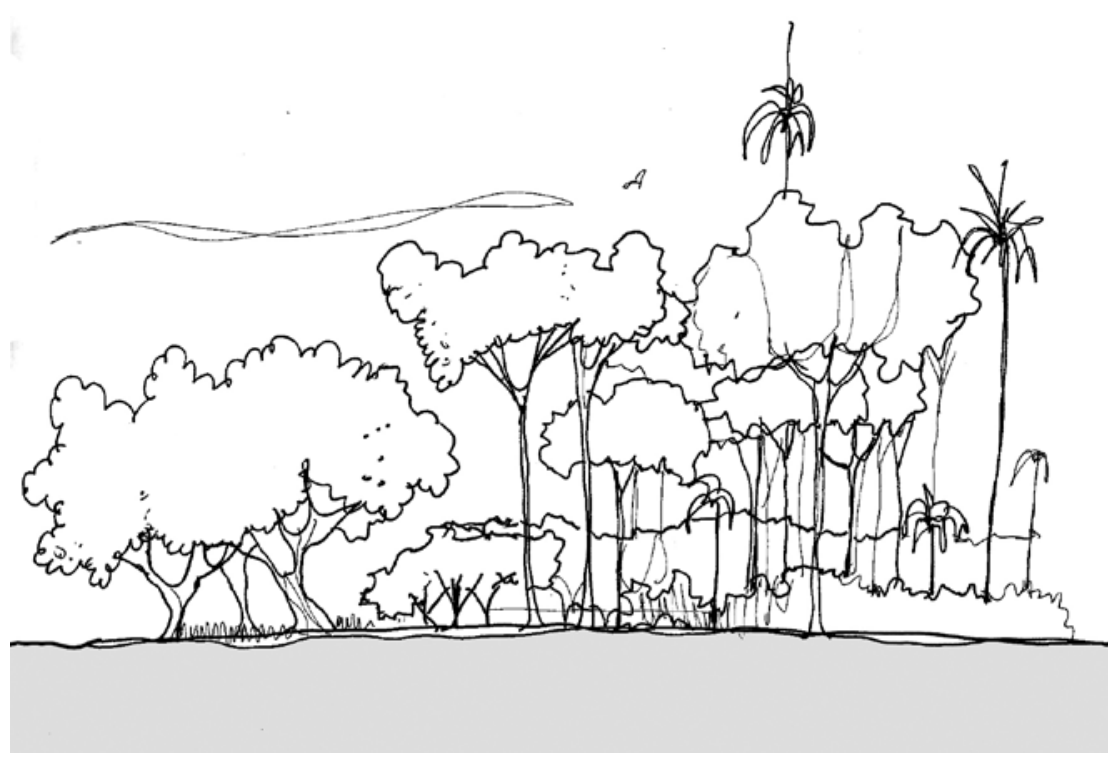

Figura 20 Bosque heterogêneo no verão.

Fonte: Desenho de Silvio Soares Macedo, 2013.

\begin{tabular}{c|c|c|c|c|c|c}
\hline Espécie & Porte & Folhagem & Folhas & $\begin{array}{c}\text { Inverno } \\
\text { (trans- } \\
\text { mitância } \\
\text { luminosa) }\end{array}$ & $\begin{array}{c}\text { Verão } \\
\text { (trans- } \\
\text { mitância } \\
\text { luminosa) }\end{array}$ & $\begin{array}{c}\text { Restrições à } \\
\text { infraestrutura }\end{array}$ \\
\hline Ligustro & Médio & Perene & $\begin{array}{c}\text { Médias, } \\
\text { verde-es- } \\
\text { curas, lisas, } \\
\text { opacas. }\end{array}$ & $39,70 \%$ & $39,20 \%$ & $\begin{array}{c}\text { Passeios sem } \\
\text { infraestrutura } \\
\text { aérea. }\end{array}$ \\
\hline
\end{tabular}




\begin{tabular}{c|c|c|c|c|c|c}
\hline Extremosa & Pequeno & Caducifólia & $\begin{array}{c}\text { Pequenas, } \\
\text { verde-cla- } \\
\text { ras, lisas. }\end{array}$ & $91,10 \%$ & $14,20 \%$ & $\begin{array}{c}\text { Passeios com } \\
\text { infraestrutura } \\
\text { aérea e sem } \\
\text { boca de lobo } \\
\text { nas proximida- } \\
\text { des. }\end{array}$ \\
\hline Cinamomo & Grande & Caducifólia & $\begin{array}{c}\text { Médias, } \\
\text { verdes e } \\
\text { escuras. }\end{array}$ & $37,10 \%$ & $10,20 \%$ & $\begin{array}{c}\text { Passeios largos } \\
\text { (>3m) sem } \\
\text { infraestrutura } \\
\text { aérea e subter- } \\
\text { rânea. }\end{array}$ \\
\hline Sibipiruna & Grande & Caducifólia & $\begin{array}{c}\text { Pequenas } \\
\text { com múlti- } \\
\text { plos folíolos, } \\
\text { verde-escu- } \\
\text { ras, lisas. }\end{array}$ & $85,00 \%$ & $12,70 \%$ & $\begin{array}{c}\text { Canteiros cen- } \\
\text { trais e passeios } \\
\text { largos sem } \\
\text { infraestruturas } \\
\text { aéreas e subter- } \\
\text { râneas. }\end{array}$ \\
\hline
\end{tabular}

Tabela 2 Transmitância luminosa e restrições à infraestrutura de algumas árvores brasileiras.

Fonte: PREAMBE, 2001.

\section{FUNÇÕES DE ENGENHARIA DA ARBORIZAÇÃO}

Robinette (1972) lista algumas características vegetais e suas aplicações em problemas de engenharia:

a) folhas grossas amortecem a polvição sonora;

b) ramos movem-se e vibram, absorvendo e mascarando a polvição sonora;

c) folhas capturam partículas de poeira;

d) estômatos nas folhas para trocas gasosas;

e) flores e folhagens que fornecem bom cheiro para mascarar o mau odor;

f) folhas e galhos para reduzir velocidade do vento;

g) folhas e galhos para reduzir a velocidade da chuva;

h) raízes expansivas para proteger o solo da erosão;

i) folhagem densa para bloquear a luz;

i) folhagem leve para filtrar a luz;

k) galhos espinhosos para deter o movimento humano.

O mais importante uso de engenharia envolvendo árvores, possivelmente seja o combate à erosão do solo, graças aos enormes impactos ambientais associados à construção. Define-se como "erosão do solo" a perda dos horizontes pedológicos superiores (A ou $O)^{\prime}$ devido à ação do vento ou da água, normalmente resultante de um manejo impróprio. A erosão gerada pelo vento está mais associada a áreas agrícolas, onde grandes porções de terra permanecem descobertas e desprotegidas das rajadas

Horizonte A: camada superior do solo, composta por partículas eluviais escuras devido à decomposição de plantas e matéria orgânica. Horizonte $\bigcirc$ : também conhecido como hístico, é formado pelo acúmulo de matéria orgânica e, em alguns tipos de solo (organossolo, por exemplo), encontrado acima do Horizonte A. 
que removem suas partículas superficiais. Entretanto, a erosão provocada pela água da chuva, através da lixiviação e pelo maquinário construtivo que revolve o solo, afeta decisivamente a floresta urbana.

Os planejadores, consensualmente, acreditam que a conservação das bacias hidrográficas seja a melhor forma de combater a erosão do solo. Isto é feito mantendo a mata ciliar encontrada nas margens dos corpos d'água e ampliando áreas florestadas, pois as árvores protegem o solo da chuva com suas copas (especialmente quando densas, no caso das coníferas) e com a camada superficial de serapilheira depositada.

Também seguram o solo com suas raízes e aumentam a absorção de água graças à incorporação de matéria orgânica e ampliação da endopedofauna (fauna subterrânea, composta por microrganismos e espécies pluricelulares, como minhocas).

A figura 20 ilustra a capacidade das copas das árvores de reterem a chuva, assim evitando alagamentos e erosão do solo. No caso, Grey (1978) demonstra a maior aplicabilidade de espécies de coníferas para esta função, que, graças às copas densas, retêm $40 \%$ da incidência pluviométrica, enquanto copas de igual porte, mas menos densas, retêm metade desse valor.

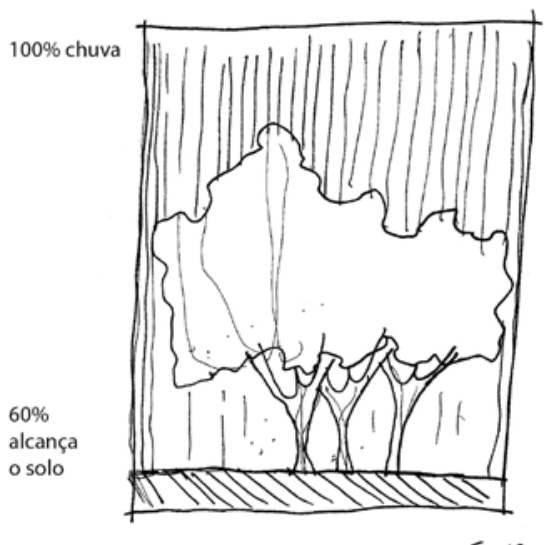

S,O13

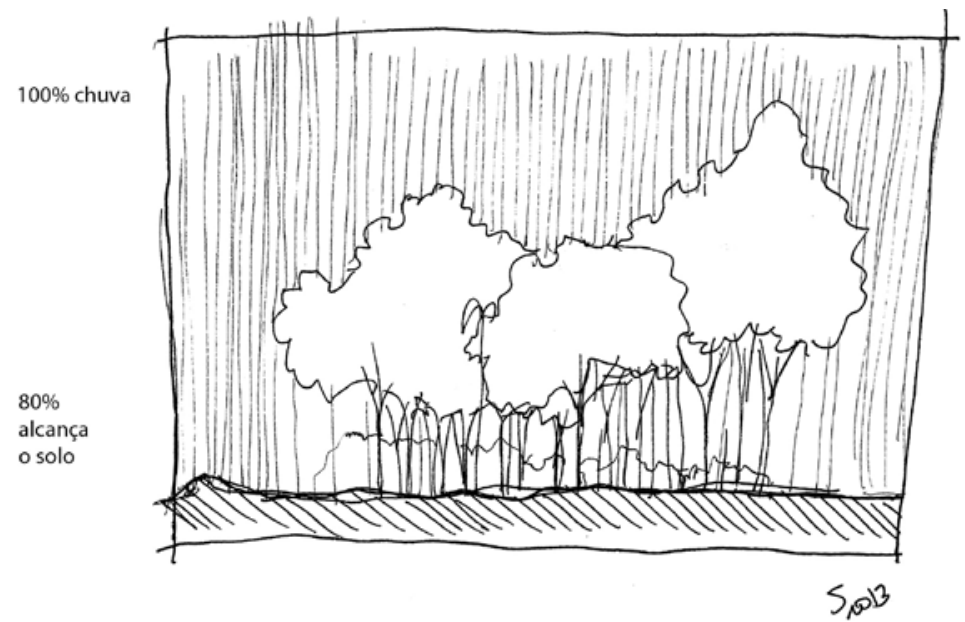

Figura 20 Árvores como barreiras naturais da chuva.

Fonte: Desenho de Silvio Soares Macedo, 2013. Adaptado de Grey (1978). 
Em termos de relevância, o uso de árvores para conter o desperdício de água vem logo a seguir. À medida que a população das cidades aumenta, aumentam também as necessidades de abastecimento, e desperdícios passam a ser bastante comuns e perniciosos, assim como o despejo de dejetos em rios, lagos, reservas e praias. Isto não é novidade alguma para qualquer habitante da cidade de São Paulo, acostumado aos enormes índices de polvição dos seus dois principais rios, o Tietê e o Pinheiros, e ao ainda constante lançamento de esgoto nas represas Billings e Guarapiranga, responsáveis por parte do abastecimento doméstico da cidade.

A limpeza de corpos d'água poluídos requer diversas etapas. Começa com a remoção de grandes objetos neles contidos, o que é sucedido por um tratamento biológico envolvendo o uso de microrganismos para decompor componentes orgânicos. Nesta etapa, 90\% dos componentes sólidos são removidos, mas ainda permanece a maior parte de elementos poluidores, como 58\% do nitrogênio e 30\% do fósforo (GREY, 1978). Estes elementos podem ser removidos em uma terceira etapa, por injeção de oxigênio, um tratamento bastante caro e, vez por outra, incompatível com zonas urbanas. Devido ao alto custo do mesmo, outras soluções precisam ser consideradas, como o land sewage disposal, em que se aplicam dejetos na terra, com quantidade e toxicidade controlada, utilizando o biossistema formado pelo solo e pela vegetação como um filtro vivo para renovar os recursos de água subterrânea e adubar a produção agrícola.

Água antropicamente alterada em residências pode ser tranquilamente utilizada, embora dejetos industriais necessitem de maior controle prévio. Para tanto, é preciso que o solo tenha alta capacidade de infiltração e permeabilidade para acomodar tais dejetos em quantidades seguras, absorver os elementos químicos utilizados nos casos mais severos, permitir a drenagem dos efluentes renovados e manter suas condições aeróbicas naturais. Sem uma cobertura vegetal, como visto previamente, os horizontes superficiais do solo são erodidos e sua serventia como "filtro vivo" é severamente comprometida.

Dentre os demais fatores de destaque na lista de Robinette (1972) sobre usos de engenharia para plantas, consta o controle da polvição sonora, a purificação do ar e a proteção contra excessiva luminosidade, potencialmente danosa para o olho humano. Embora Grey (1978) afirme que arbustos de coníferas reduzem em 50\% o ruído gerado pela coleta de lixo a 27,5 m de distância, e árvores coníferas e decíduas - superiores a $2 \mathrm{~m}$ de altura - diminuam em $40 \%$ o barulho de um cortador de gramas que chega à rua, a relevância da vegetação para conter a polvição sonora tem sido superestimada. $\mathrm{Na}$ realidade, um único $\mathrm{dB}$ de redução requer muitos $\mathrm{m}^{2}$ contínuos de vegetação, e seus efeitos de purificação do ar ainda são inconclusivos. Já os efeitos psicológicos da vegetação na paisagem não demonstraram ser irrelevantes.

De acordo com a teoria da "Biofilia", seres humanos são naturalmente propensos a apreciar o contato com outros seres vivos, sejam eles animais ou plantas (WILSON, 1984). Desta forma, os poucos rincões verdes das grandes cidades são disputados e apropriados pelo mercado, sendo áreas residenciais arborizadas - ou próximas de grandes parques - mais valorizadas que as demais, como demonstram os mapas 
elaborados durante esta pesquisa e mesmo dados norte-americanos, que revelam serem casas defronte a uma única grande árvore, 0,88\% mais caras que as demais (ANDERSON; CORDELL, 1988).

\section{VEGETAÇÃO, PAISAGEM E O SISTEMA DE ESPAÇOS LIVRES URBANOS}

É consenso entre pesquisadores do espaço urbano a importância da vegetação e os benefícios que ela traz à população residente das cidades. Dentre os espaços vegetados, destacam-se os de áreas permeáveis e as florestas urbanas. Os primeiros suavizam o impacto pluviométrico, permitindo a absorção das gotas da chuva e evitando enchentes onde o relevo e o asfalto acumulariam uma grande quantidade de água. Já as florestas exercem variadas funções estéticas, arquitetônicas e ambientais. Este texto dissertará brevemente sobre os objetos naturais e a paisagem urbana.

Dentre todos os conceitos ambientais, "área verde" é, possivelmente, a terminologia de maior conhecimento popular. Llardent (1982) define área verde como "[...] Qualquer espaço livre no qual predominam as áreas plantadas de vegetação, correspondendo, em geral, ao que se conhece como parques, jardins ou praças".

Já Lima et al. (1994) define área verde como todo lugar onde existe o predomínio de vegetação arbórea, como praças, parques, jardins e até canteiros. Entretanto, exclui da definição árvores acompanhando vias públicas, já que estas crescem sobre solos praticamente impermeabilizados.

Sendo toda vegetação urbana de grande porte interessante à pesquisa, o conceito de áreas verdes torna-se pouco relevante para a mesma, levando-me a adotar o conceito de "espaços livres" em seu lugar. Estes podem ser arborizados ou não, paisagisticamente tratados ou não.

Nas áreas urbanas, o espaço livre é todo aquele não ocupado ou coberto por um volume edificado (MAGNOLI, 2006). É destinado à circulação de pessoas, veículos e mercadorias, interiorização de ar e luz, recreação e conservação ambiental. De acordo com Macedo (1995), são espaços livres as ruas (leito carroçável e calçadas), praças, largos, pátios, quintais, jardins, terrenos baldios, corredores externos, vilas, vielas e outros mais por onde circulam pessoas em seus cotidianos.

Sendo a construção da cidade condicionada por sua estrutura fundiária, o mesmo ocorre quanto à apropriação de seus espaços. A propriedade do solo - dividida em pública e privada - reparte os espaços livres existentes entre ambas as categorias. Quando públicos, podem ser divididos em três subgrupos pelo Código Civil, de acordo com Menneh (2002):

a) áreas de uso comum: usufruídas sem restrições, onde se enquadram ruas, praças, parques - quando não destinados à conservação - e canteiros;

b) áreas de uso especial: espaços à disposição para atividades ou serviços públicos; 
c) áreas dominicais ou dominiais: de uso restrito, não aplicadas ao uso comum e nem ao especial.

Tunnard e Pushkarev (1964) ligam os espaços livres à produção de alimentos, extração de recursos naturais, geração e fornecimento de energia, abastecimento e tratamento da água, cultura de animais e plantas ornamentais, entre outros. São áreas de proteção aos recursos naturais e culturais, circulação urbana, práticas recreativas e atividades sociais. Configuram também áreas de segurança pública, por possibilitarem o controle do deslizamento de encostas na ocupação das faixas de inundação e, também, de áreas potencialmente incendiáveis. Abramsom (1981) afirma representarem "[...] a qualidade de vida e a 'vivibilidade' de uma cidade [...]", enquanto Furlan et al. (2004) ainda atribuem aos espaços livres funções ecológicas e socioambientais, através das áreas verdes e corredores arbóreos.

De acordo com Silva (2004), é através do espaço que são impressas as mudanças na sociedade. Os espaços livres, pela capacidade de atrair grande quantidade de pessoas, possuem enorme destaque na paisagem urbana. Macedo (1993) entende a existência da paisagem urbana como produto e sistema: produto, por ser resultado de um processo social de ocupação e gestão do território que gerou os até então mencionados espaços livres; sistema, por apresentar reações a quaisquer ações sobre ela impressa, equivalendo ao surgimento de uma alteração morfológica parcial ou total. A ideia de "sistema" está ligada à relação de interdependência mantida pelos espaços livres de uma cidade. Isto não ocorre apenas por estarem conectados através de um sistema viário que dá acesso a um espaço livre através de outro, mas por responderem a alterações ocorridas em outra parte do sistema. Como exemplo, um espaço livre inclinado, pouco arborizado e impermeável geraria, durante as chuvas, mais impactos em outros espaços que um igualmente inclinado, porém permeável e amplamente vegetado. Macedo (1993) ainda atribui três aspectos qualitativos à paisagem:

a) qualidade ambiental: mede as possibilidades de vida e sobrevida de todos os seres vivos e de suas comunidades;

b) qualidade funcional: avalia o grau de eficiência do lugar no tocante ao funcionamento das sociedades humanas;

c) qualidade estética: valores com características puramente sociais que cada comunidade, em um momento do tempo, atribuiu ao lugar.

As qualidades funcionais e ambientais da paisagem costumam manter relação de interdependência, posto que a existência de árvores, essencial para a qualidade ambiental da cidade tropical, tem como pré-requisito um espaço livre adequado, capaz de comportar indivíduos adultos. Dentre os problemas mais frequentes neste sentido estão as raízes que se expandem e destroem parte da calçada; árvores que crescem demasiadamente, entrando em conflito com a fiação elétrica ou obstruindo a passagem de pedestres; quedas durante as tempestades, danificando veículos, casas e ferindo pessoas. Desta forma, copas densas seriam compatíveis com locais de paradas (como 
praças e calçadas muito amplas), enquanto as menores não conflitariam com a fiação dos postes (que, idealmente, deveria estar por baixo da terra), as canalizações subterrâneas e as passagens de pedestres. Este espaço livre requerido para o cultivo pode ser dividido em dois grupos:

a) extralote: espaços arborizáveis fora dos lotes, como passeios, parques, praças e canteiros centrais;

b) intralote: inclui todo espaço livre de volumes edificados dentro do lote (desde pátios e jardins a áreas não construídas, por atender às taxas exigidas de recuo, ocupação máxima e permeabilidade mínima).

Na maioria dos bairros paulistanos predominam lotes pequenos, situados em quadras com passeios de largura mínima e pouquíssimas praças. $\bigcirc$ plantio de árvores grandes o suficiente para amenizar o desconforto térmico da cidade é impossibilitado em quadras deste tipo, ao contrário do que ocorre nos grandes lotes, onde as áreas construídas e pavimentadas ocupam apenas parte da gleba, permitindo o aparecimento do estrato arbóreo (ABBUD, 1986).

\subsection{ARBORIZAÇÃO INTRALOTE}

O parágrafo XV do Art. 146 do Plano Diretor Estratégico de São Paulo chama de "índice de cobertura vegetal" a relação entre a parte permeável coberta por vegetação e a área do lote. Ainda que árvores, acompanhando ruas e avenidas, cresçam sobre solos praticamente impermeabilizados (em muitos casos com espaço adequado para seu crescimento e circulação de pedestres), chega a ser redundante afirmar que a permeabilidade do solo facilita a arborização. A lei municipal, Portaria 156/09 SVMA, de 10 de dezembro de 2009, aumentou de 15\% para 20\% a taxa mínima de permeabilidade para qualquer lote da cidade?

Nos pequenos lotes, tais percentuais tornam-se irrelevantes, mas quanto maior a área absoluta permeável provinda destas frações, maior a possibilidade de um trabalho paisagístico expressivo. Prédios de apartamentos encontram-se em médios ou grandes lotes devido à área mínima e presença de recuos exigidos, tornando zonas verticalizadas potencialmente vegetadas. Entretanto, historicamente, quase inexistiu, na maior parte delas, vegetação de médio ou grande porte, pois com frequência o jardim do pavimento térreo assentou-se sobre a laje que cobria a garagem (ABBUD, 1986).

Em São Paulo, a existência de árvores em lugares que não reúnem condições mínimas e sua ausência onde poderiam ser benéficas sempre foi registrada. Em diversos projetos condominiais, inclusive nos mais recentes, com torres isoladas no centro do lote, a área permeável encontra-se inteiramente distribuída às "margens" do mesmo, formando uma pequena fresta perimetral de solo descoberto ao invés de agrupar-se em um só canto, onde diversas árvores poderiam ser cultivadas. Algumas cidades exigem 
que parte desta área permeável intralote esteja agrupada, embora isto não ocorra em São Paulo, onde tal prática é apenas aconselhada.

Em Maringá (PR), por exemplo, a Lei Complementar n 331/99, em seu Artigo 26 afirma que "[...] 50\% (cinquenta por cento), no mínimo, da área permeável deverão estar contidos em uma área única.". $\bigcirc$ mesmo para Gravataí, onde a Lei Municipal n 3429, Artigo $12^{\circ}, \S 2^{\circ}$, exige que o "[...] dimensionamento da área permeável, 30\% (trinta por cento), no mínimo, terão que estar contidos em uma área única.". Já em São Paulo, a Portaria 156/09 da Secretaria do Verde e do Meio Ambiente (SVMA), de 10 de dezembro de 2009, afirma no segundo artigo:

"[...] nos processos de licenciamento de novos parcelamentos do solo ou projetos de edificação urbana, sem prejuízo das demais medidas mitigadoras pertinentes, deverá ser exigida a manutenção das características naturais de permeabilidade do solo em, no mínimo, 20\% (vinte por cento) da área total do imóvel, preferencialmente em bloco único, visando assegurar, entre outros aspectos, a infiltração das águas pluviais, a conservação da biodiversidade, a mitigação da formação de ilhas de calor e da polvição sonora e atmosférica."3

padrão de condomínios verticais com torres isoladas, comumente utilizado pelo mercado imobiliário na cidade de São Paulo (por razões que não cabem aqui serem abordadas), poderia representar um enorme aporte ao índice de cobertura vegetal urbano, mas, na ausência de uma regulamentação específica, isto nem sempre ocorre. Embora alguns projetos de fato apresentem áreas permeáveis contínuas, nos menores lotes verticalizáveis isto quase nunca ocorre, posto que a lei de recuos leva as construtoras a deixar a torre no centro do lote, havendo uma tendência a manter sob a mesma todo o equipamento condominial, relegando às margens a porção permeável exigida. Ainda assim, condomínios verticais da área de estudo são mais arborizados que a grande maioria das outras tipologias construídas, não sendo possível afirmar que o mercado imobiliário seja um empecilho para a arborização da cidade. No caso presente, a própria lei, que, em tese, estimula a permeabilização e arborização, como visto no art. 56 ("IV - a ampliação das áreas permeáveis no território do Município") e 59 ("IV - a manutenção e ampliação da arborização de ruas, criando faixas verdes que conectem praças, parques ou áreas verdes) do Plano Diretor Estratégico da Cidade de São Paulo, o lote é responsável por um projeto condominial "menos verde" do que poderia ser.

\subsection{A ARBORIZAÇÃO EXTRALOTE}

Em São Paulo, sendo pequena a maior parte dos lotes - com pátios ou quintais cimentados - e sendo a arborização, nos grandes, menos expressiva do que poderia ser, as calçadas, ainda que predominantemente estreitas, abrigam a grande maioria dos indivíduos arbóreos. Devido às interferências causadas no espaço urbano, um projeto 
de arborização em vias públicas precisa do aval de órgãos responsáveis pelo licenciamento de obras e instalação de equipamentos, como o Departamento de Controle de Uso de Vias Públicas (CONVIAS/SIURB), o Departamento de lluminação Pública (ILUME/SES), o Departamento do Sistema Viário (DSV/SMT) e a Secretaria Municipal de Subprefeituras (SMSP).

O estabelecimento de faixas permeáveis é essencial para a arborização extralote, seja na forma de canteiros, quanto na de pisos drenantes. De acordo com o Manual Técnico de Arborização Urbana (2005) da Secretaria do Verde e do Meio Ambiente (SVMA) da Cidade de São Paulo, a área destas faixas depende do tamanho da copa, uma vez que a expansão das raízes tende a alcançar o mesmo diâmetro. Para copas pequenas, com aproximadamente $4,0 \mathrm{~m}$ de diâmetro, canteiros de $2,0 \mathrm{~m}^{2}$ são suficientes. As copas grandes ( $8,0 \mathrm{~m}$ de diâmetro) exigem canteiros ligeiramente maiores, de 3,0 $\mathrm{m}^{2}$, sendo necessários $1,50 \mathrm{~m}$ de espaço mínimo recomendável e 1,20 m de espaço mínimo exigido para a circulação, conforme a Norma Brasileira (NBR) 9050 (2004), da Associação Brasileira de Normas Técnicas (ABNT).

O Manual Técnico... divide as árvores por espécie de acordo com o porte, adequando o seu plantio às condições existentes. São classificadas como de pequeno porte árvores de até 5,0 m de estatura; de médio porte, as que tiverem entre 5,0 m e 10,0 $\mathrm{m}$; de alta estatura, todas as que excederem esta marca. Entretanto, estes intervalos arbitrários não consideram a variação normal de crescimento dentro da mesma espécie. O tamanqueiro (Alchornea glandulosa), o tingui preto (Dictyoloma vandellianum) e a guaxupita (Esenbeckia grandiflora), por exemplo, todas elas nativas, podem alcançar de 4,0 m a 7,0 m de altura. Se cultivados em um espaço capaz apenas de comportar indivíduos de pequeno porte, podem surpreender e extrapolar os limites esperados. $O$ angelim-doce (Andira fraxinifolia) tende a ser de médio porte, porém, alguns indivíduos atingem 12,0 m quando adultos. Desta forma, nota-se um forte subjetivismo na escolha das espécies utilizadas, requerendo conhecimento empírico de um profissional e não a simples consulta da tabela. O plantio de árvores deverá seguir as recomendações contidas na tabela 3 .

\begin{tabular}{c|c|c|c|c|c}
\hline $\mathrm{P}$ - largura do passeio $(\mathrm{m})$ & $\mathrm{P}<1,5$ & $\begin{array}{c}1,5 \leq \mathrm{P} \\
<2\end{array}$ & $\begin{array}{c}2 \leq \mathrm{P}< \\
2,4\end{array}$ & $\begin{array}{c}2,4 \leq \mathrm{P} \\
<3\end{array}$ & $\mathrm{P} \geq 3$ \\
\hline Porte & não plantar & pequeno & médio & $\begin{array}{c}\text { médio e } \\
\text { grande }\end{array}$ & grande \\
\hline $\mathrm{h}$ - altura máxima $(\mathrm{m})$ & não plantar & $\mathrm{h}=5$ & $\mathrm{~h}=8$ & $\mathrm{~h}=12$ & $\mathrm{~h}>12$ \\
\hline
\end{tabular}

Tabela 3 Recomendações para o plantio conforme as características do passeio. Fonte: SECERETARIA DO VERDE E MEIO AMBIENTE (2005).

O distanciamento entre as árvores é uma variável essencial para a acomodação de guaritas, pontos de táxi, bueiros, garagens, pontos de ônibus, postes, semáforos e quaisquer outros equipamentos urbanos posicionados sobre o passeio. $\bigcirc$ Manual Técnico de Arborização Urbana da Prefeitura da Cidade de São Paulo (2005) de- 
talha a questão, apresentando a distância recomendável entre árvores e entre árvores e equipamentos urbanos, conforme a tabela 4.

\begin{tabular}{c|c|c|c}
\hline \multirow{2}{*}{ elementos } & \multicolumn{3}{|c}{ distância (m) } \\
\cline { 2 - 4 } & pequeno porte & médio porte & grande porte \\
\hline esquina & 5,00 & 5,00 & 5,00 \\
\hline iluminação pública & evitar interferências com cone de iluminação \\
\hline postes & 3,00 & 4,00 & 5,00 \\
\hline $\begin{array}{c}\text { placas de identificação e } \\
\text { sinalizações }\end{array}$ & a visão de outros usuários não deve ser obstruída \\
\hline $\begin{array}{c}\text { instalações subterrâneas } \\
\text { mobiliário urbano (bancas, } \\
\text { cabines, telefones) }\end{array}$ & 1,00 & 1,00 & 1,00 \\
\hline caixas de inspeção & 2,00 & 2,00 & 3,00 \\
\hline fachadas de edificação & 2,00 & 2,00 & 3,00 \\
\hline \multirow{2}{\text{guiarebaixada}}{} & 2,40 & 2,40 & 3,00 \\
\hline \multirow{2}{*}{\begin{tabular}{c} 
espécies arbóreas \\
\cline { 2 - 4 }
\end{tabular}} & (pode ser adotada a média aritmética, caso as espécies \\
\cline { 2 - 4 } & \multicolumn{3}{|c}{ tenham porte diferente) } \\
\hline
\end{tabular}

Tabela 4 Espaçamento recomendável entre árvores e entre árvores e equipamentos urbanos. Fonte: SECERETARIA DO VERDE E MEIO AMBIENTE (2005).

Recai sobre os passeios a parte mais importante da análise prévia ao processo de arborização urbana. De acordo com o Manual Técnico..., para cultivo apropriado os passeios deverão ter largura mínima de 2,40 m em locais desprovidos de recuo frontal - ou 1,50 m caso ele exista. Se a largura for inferior a 1,50 m, o plantio sequer é recomendado. Quando estiver entre 1,50 m e 2,0 $\mathrm{m}$, recomenda-se apenas o plantio de indivíduos de pequeno porte. Entre 2,0 m e 2,4 m, podem ser plantadas árvores pequenas e médias (de até 8,0 m de altura) - e a partir dos 2,4 m indivíduos de grande porte já são bem-vindos.

Entretanto, espécies que superam os 12,0 m de estatura devem apenas ser incorporadas a passeios com largura superior a 3,0 m. Sob fiação elétrica, apenas árvores pequenas, de até 5,0 m são recomendáveis. Caso a muda não seja plantada no alinhamento da rede e a copa da árvore seja precocemente conduzida acima da mesma, o cultivo de árvores de grande porte torna-se possível.

\section{MATERIAIS E MÉTODOS}

Ficando, então, evidentes os benefícios trazidos às grandes cidades tropicais pela presença vegetal, torna-se desejável a quantificação cartográfica e classificação das principais massas arbóreas dentro da área de estudo antes de qualquer análise sobre a mesma. Um dos principais métodos de quantificação e classificação de arborização 
urbana foi proposto pelo biogeógrafo chinês Jim (1989) ao investigar as características do dossel arbóreo e desenvolvimento urbano de Hong Kong em 1989.

A metodologia consiste no mapeamento de corredores arbóreos evidentes no espaço urbano a partir de imagens de satélite em escala 1:8.000 e sua caracterização a partir do grau de conectividade encontrado. Posteriormente, trabalhos de campo complementariam a análise das imagens através da observação qualitativa de adensamentos de difícil detecção.

Jim (1989) elaborou categorias hierárquicas para classificar a disposição da cobertura arbórea no meio urbano, que se subdividem em "isolada", "linear" e "conectada", como demonstra a figura 21.

O mapeamento foi realizado utilizando software Arcgis 9.3, um Sistema de Informações Geográficas (SIG), imagens aéreas georreferenciadas, Google Earth e Google Earth Street View. Sobre a imagem aérea, foi georreferenciado um layer de polígonos, representando as quadras da cidade de São Paulo, como demonstrado na figura 22.

Em seguida, criam-se os campos desejados na tabela de atributos do layer de quadras referentes a variáveis urbanas de forma e uso, com as quais se pretende um cruzamento visual com a existência ou não de árvores, como demonstrado na figura 23. No caso, optou-se por "espaços livres", "tipologia construída" e "recuo do lote". Cada quadra apresentará seus próprios valores para as três variáveis, entretanto, como todas fazem parte do layer de quadras, todas terão um espaço para a inserção de valores referentes aos três campos.
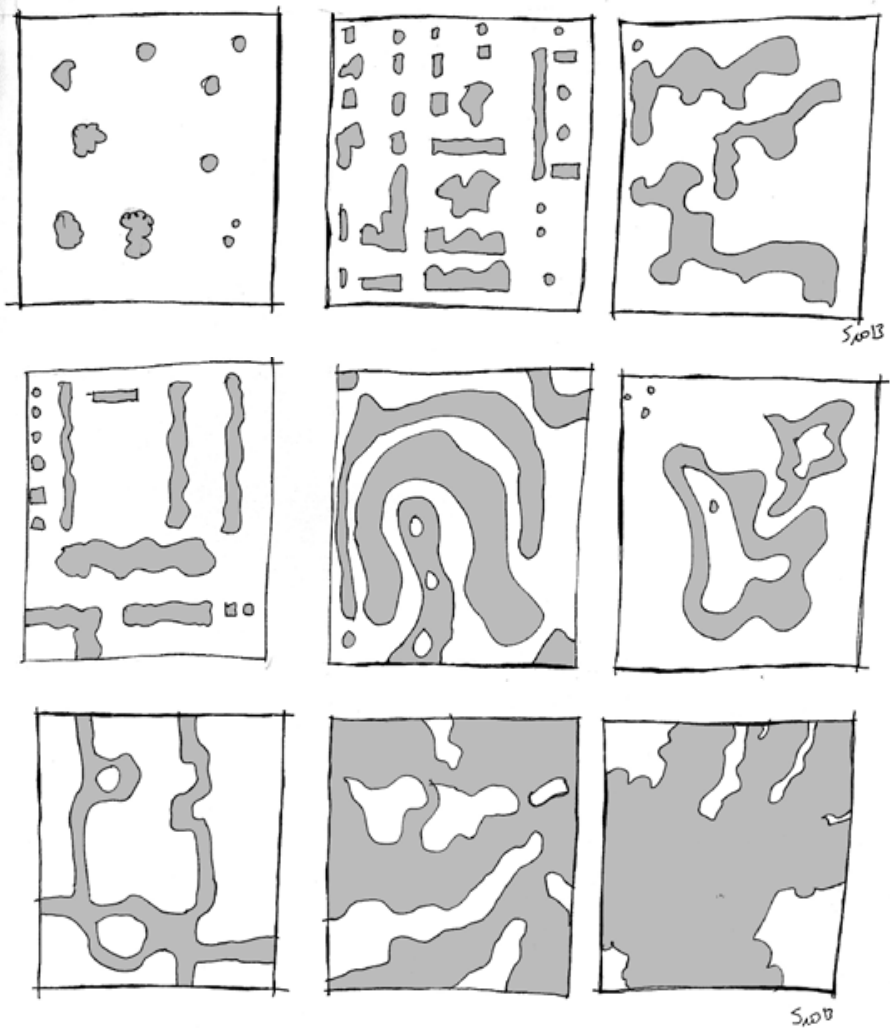

Figura 21 Tipo de cobertura arbórea.

Fonte: Desenho de Silvio Soares Macedo, 2013. Adaptado de $\operatorname{Jim}(1989)$. 


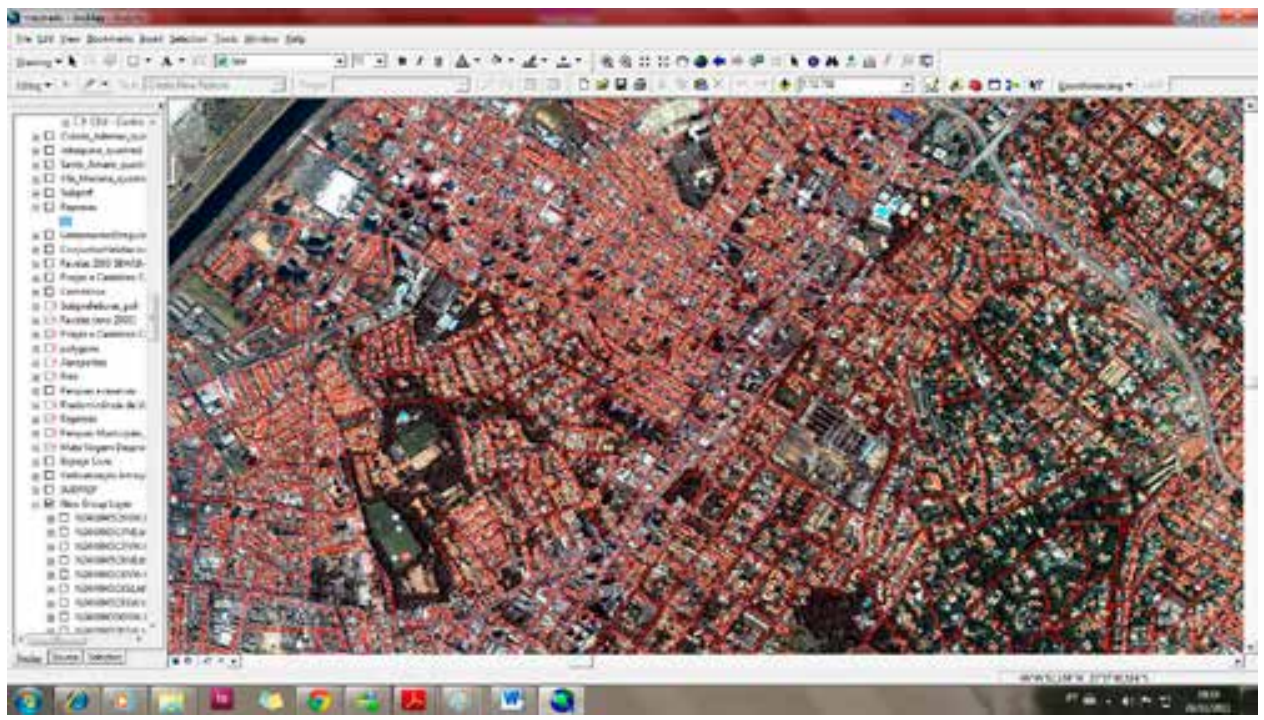

Figura 22 Posicionamento do layer de quadras. Fonte: Acervo do autor, 2011.

No caso de espaços livres, "1" representou "de 0 - 30\%"; "2" representou "de 30 - 50\%" e "3" representou "de 50 - 100\%". O mesmo foi feito no caso da tipologia construída $(1-9)^{4}$ e do recuo do lote $(1-5)^{5}$.

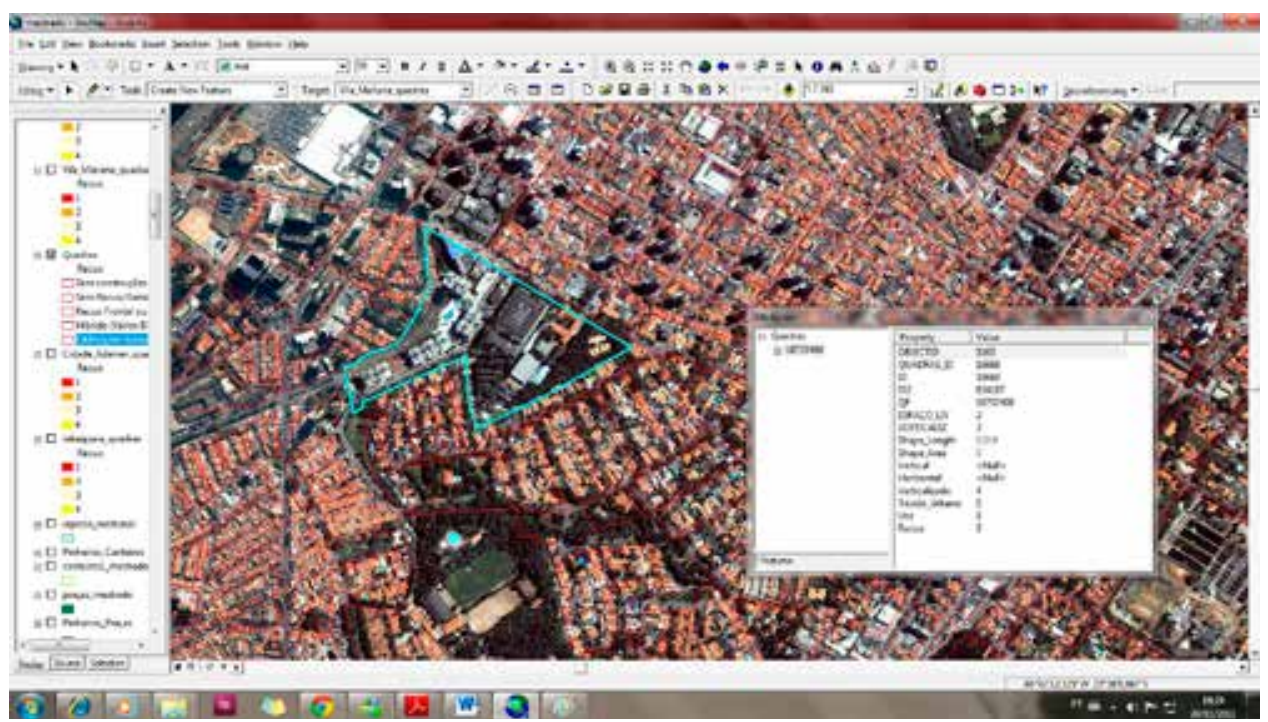

Figura 23 Inserção de valores na atribute table. Fonte: Acervo do autor, 2011.

4 Sem construções, Misto (casa + edifício), instituições em quadras isoladas (hospitais, escolas, igrejas), grandes estruturas (galpões, indústrias, shoppings, centros de convenções), conjuntos habitacionais (público/privado, até quatro andares), loteamentos fechados residenciais (casas), condomínios horizontais residenciais, quadras condominiais verticais, quadras verticalizadas, quadras $100 \%$ horizontais, quadras mistas (casario, instituições e galpões).

5 Sem recuo (construções geminadas), recuo frontal (fundos geminados), recuos em geral (construções isoladas ou semi-isoladas), quadras híbridas (mais de um elemento presente) e quadras vazias 
Em cada quadra das Subprefeituras de Santo Amaro e Cidade Ademar, foi preciso inserir manualmente os valores correspondentes aos três campos da tabela de atributos. Posteriormente, cada valor foi associado a uma cor, já que a finalidade do mapa temático é representar visualmente informações quantitativas (figura 24).

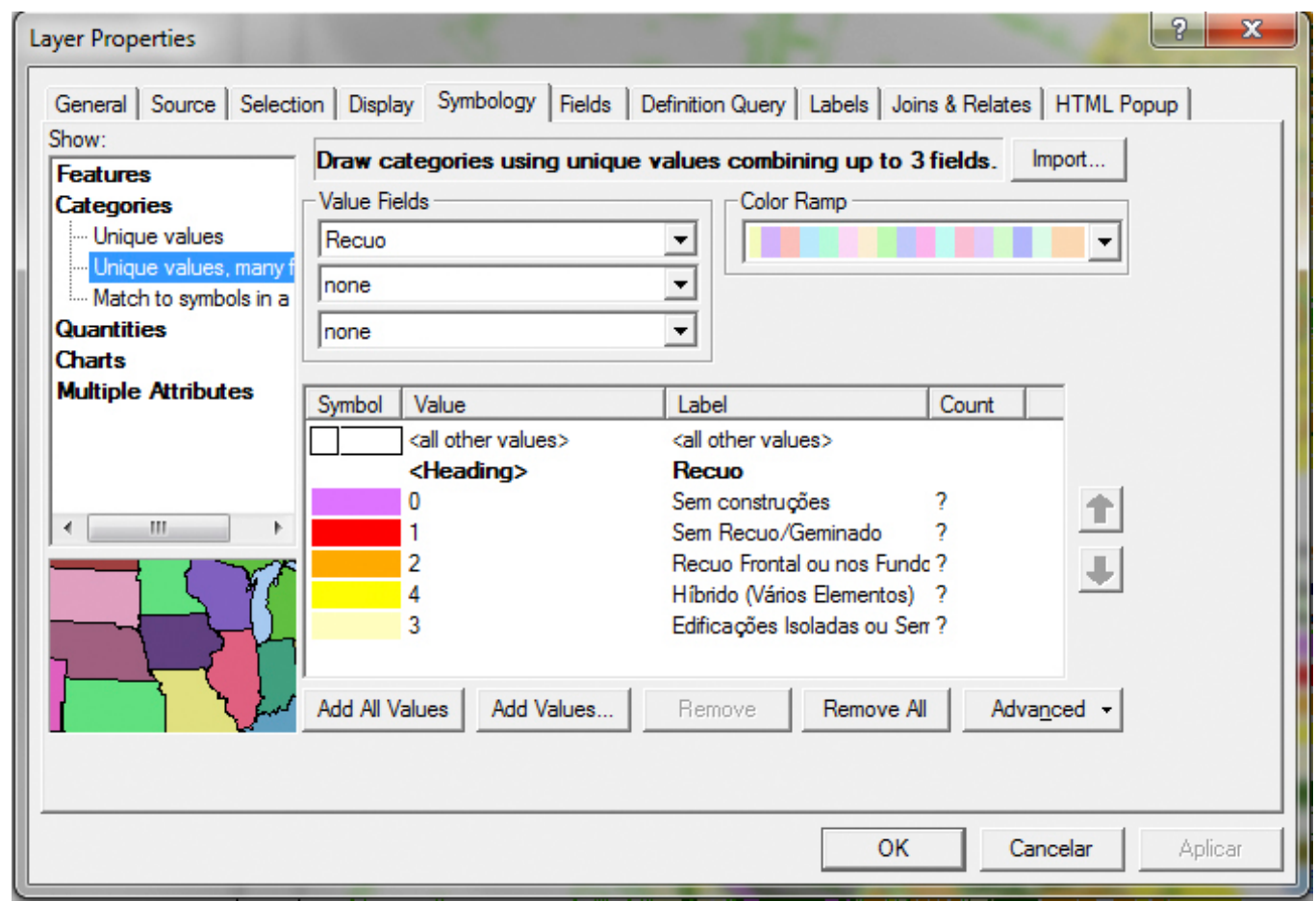

Figura 24 Associação de valores e cores.

Fonte: Acervo do autor, 2011.

A escolha das cores deve facilitar a identificação das variáveis. No caso dos recuos, o vermelho mais forte e quente foi associado a lotes geminados, isto é, sem espaços laterais entre uma construção e outra e sem recuos frontais. A escolha de uma cor intensa é mais facilmente associável a um lote geminado do que a outros, de edificações isoladas ou parcialmente isoladas, para os quais optei por tom pastel claro. Para os valores intermediários, quanto mais geminados, cores mais intensas.

\subsection{VETORIZAÇÃO}

Uma etapa à parte na elaboração dos mapas é a vetorização de layers. Feature classes informando a localização de parques, praças, canteiros, cemitérios, reservas e massas arbóreas foram inseridos sobre todos os mapas, com a finalidade de relacionar estes objetos do espaço com as variáveis identificadas (espaços livres, tipologia construída, recuo dos lotes e malha viária). No caso, a base de dados do Laboratório Quadro de Paisagismo no Brasil (LABQUAPÁ) já disponibilizava shapefiles (arquivo vetorizado em linhas ou polígonos contendo informações geográficas, como datum e coordenadas) dos parques de São Paulo, assim como a localização de suas praças 
e canteiros centrais. Bastou apenas inseri-los na tabela de conteúdos para que fossem espacializados sobre os mapas deste trabalho. Entretanto, não havia informação geográfica alguma sobre a localização de cemitérios, represas e principais massas arbóreas. Neste caso, tais informações precisaram ser manualmente vetorizadas. Para tanto, deve-se inicialmente criar um shapefile - ou arquivo em GDB - no ArcCatalog, inserir o datum e coordenadas usados nos outros elementos já contidos no mapa, para só depois inseri-lo no ArcMap. Feito isto, basta selecionar o novo layer, sua cor e desenhá-lo sobre a foto georreferenciada. A figura 25 mostra massas arbóreas sendo vetorizadas sobre a foto. Nota-se que o shapefile de "Massas Arbóreas" está selecionado, assim como a ação Create New Feature.

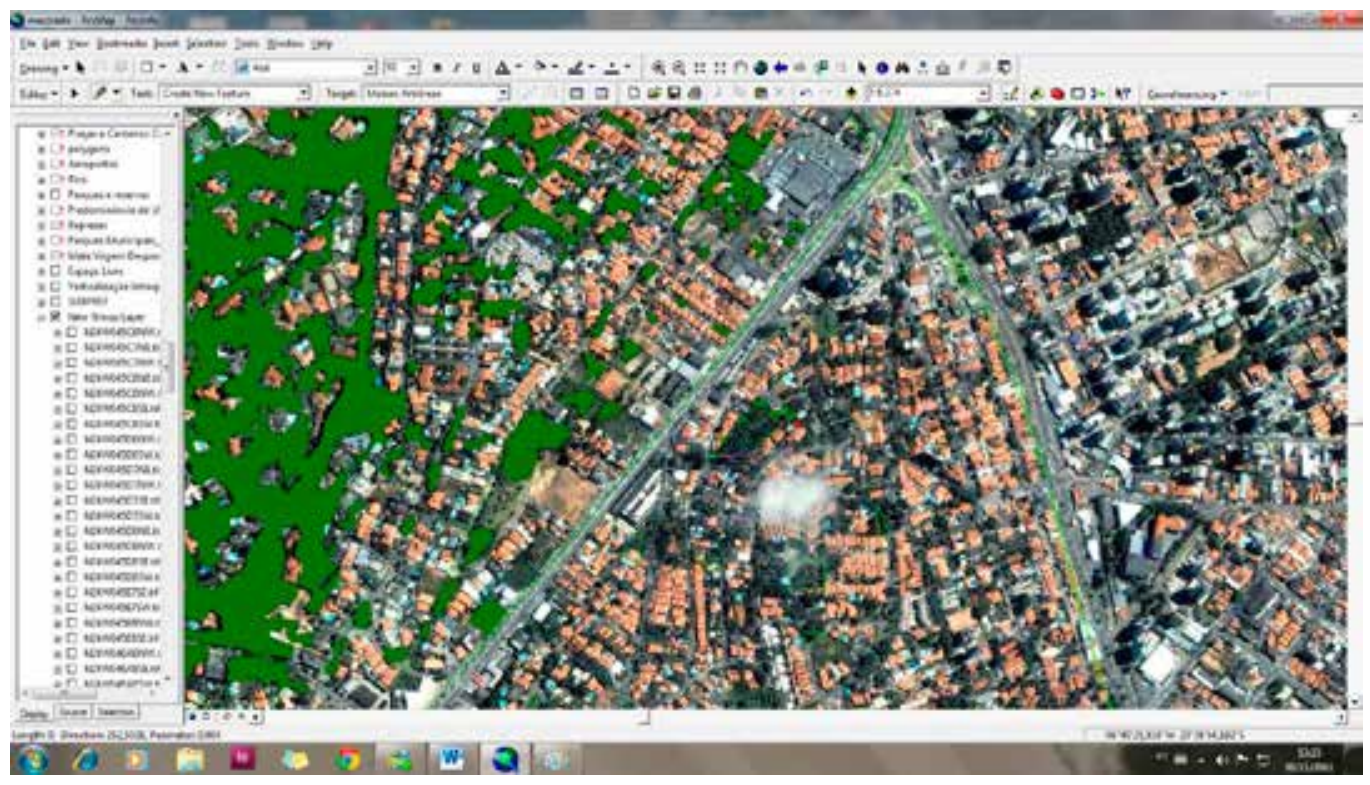

Figura 25 Vetorização das massas arbóreas. Fonte: Acervo do autor, 2011.

Na etapa final, acertam-se os detalhes de layout: formato, legenda, norte, título e formatação. Cada mapa deve ser transformado em PDF (600 dpis) para reduzir o tamanho do arquivo antes de impresso. Ainda assim, apenas a visualização do arquivo físico permite a detecção de alguns erros (sempre existentes).

Uma segunda metodologia de mapeamento da arborização urbana pode ser destacada caso estejam disponíveis imagens com bandas vermelhas e infravermelhas (figura 26). Neste caso, usa-se a ferramenta Raster Calculator do Spatial Analist (no ArcGis) para determinar o Normalized Difference Vegetation Index (NDV) da imagem, consistindo tal procedimento em detectar as zonas de maior incidência infravermelha. ${ }^{6}$

No "Raster Calculator" usa-se a fórmula: Float (Banda 2 - Banda 3) / Float (Banda $2+$ Banda 3). Após o comando "evaluate", um novo layer de imagem aparecerá no atribute table. Este ainda deverá passar por algumas modificações. Um duplo clique no novo layer Calculation permite mudar, na opção Symbology o type para none. Após o comando "aplicar", repete-se a operação mudando o type para Standard Deviations. O resultado será o total destaque de áreas vegetadas que poderão ser posteriormente transformadas em shapefile. 
Lembrando que espécies vegetais absorvem enormes quantidades de radiação infravermelha (entre 400 e 700 nanômetros) para realização da fotossíntese, sua identificação automática torna-se possível por este procedimento. Embora exista um enorme ganho em tempo no uso deste procedimento, as tentativas realizadas demonstram certa dificuldade em diferenciar gramados de dosséis arbóreos, o que não ocorreria com o olho humano.

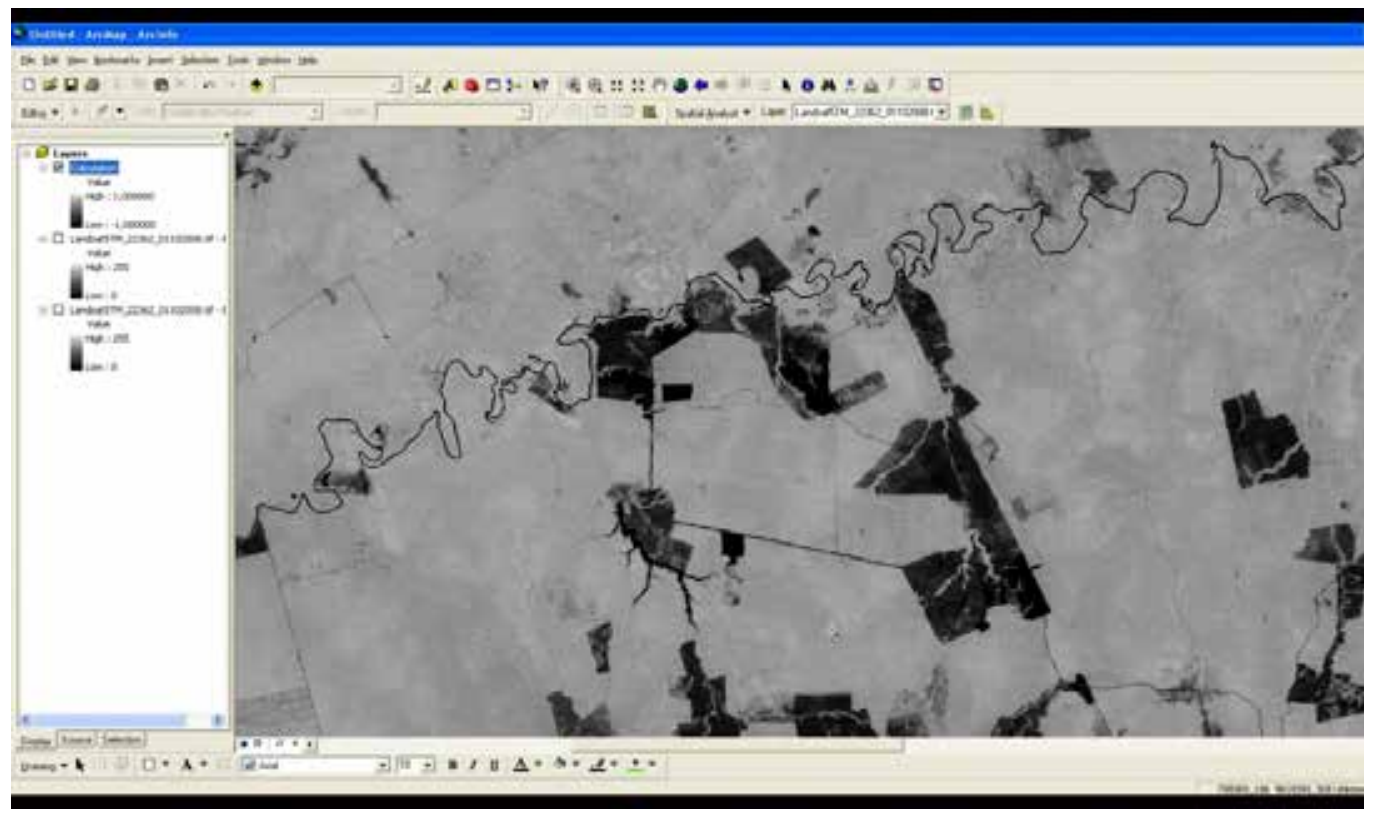

Figura 26 Uso do NDVI.

Disponível em: <http://www.youtube.com/watch?feature=player_embedded\&v=wWWHAUWSTI\#! >. Acesso em: 2012.

\section{CONCLUSÃO}

A espacialização de variáveis urbanas referentes à forma e ao uso (como espaços livres, tipologia construída ou recuo do lote) e o seu confrontamento visual com a existência, ou não, de árvores permite uma leitura aprofundada sobre a dinâmica e a disposição da natureza dentro da paisagem urbana e, consequentemente, sobre o sistema de espaços livres da cidade. Particularmente, nesta pesquisa, verifica-se como a arborização estrutura o espaço livre e como a sua existência é determinada por ele.

$\mathrm{Na}$ área de estudo, além dos parques, das praças, dos canteiros e cemitérios, encontrou-se uma cobertura vegetal adequada em termos paisagísticos em poucos bairros da subprefeitura de Santo Amaro. São eles o Jardim dos Estados, com 25\% da área das quadras coberta por dosséis arbóreos, o Alto da Boa Vista, com 32\% da área das quadras coberta por dosséis arbóreos, e a Chácara Flora, com 60\% da área das quadras coberta por dosséis arbóreos, correspondendo aos tipos Reticulado, Linear e Ramificado, respectivamente (figuras 27 e 28). 
Estes espaços, dentre os mais arborizados da cidade, contrastam fortemente com a quase inexistência de árvores na subprefeitura vizinha, de Cidade Ademar, e suas cercanias na subprefeitura de Santo Amaro. O mapeamento demonstra que a existência de uma arborização expressiva depende da oferta de espaço urbano (figuras 29 e 31). Como regra geral, quanto mais espaços livres de volumes edificados uma quadra tiver, maiores seus lotes tendem a ser e mais recuos suas edificações tendem a apresentar, sendo também, consequentemente, maior o espaço arborizável. Existe, portanto, uma correlação diretamente proporcional entre espaços livres, tamanho dos lotes, quantidade de recuos, renda e arborização.

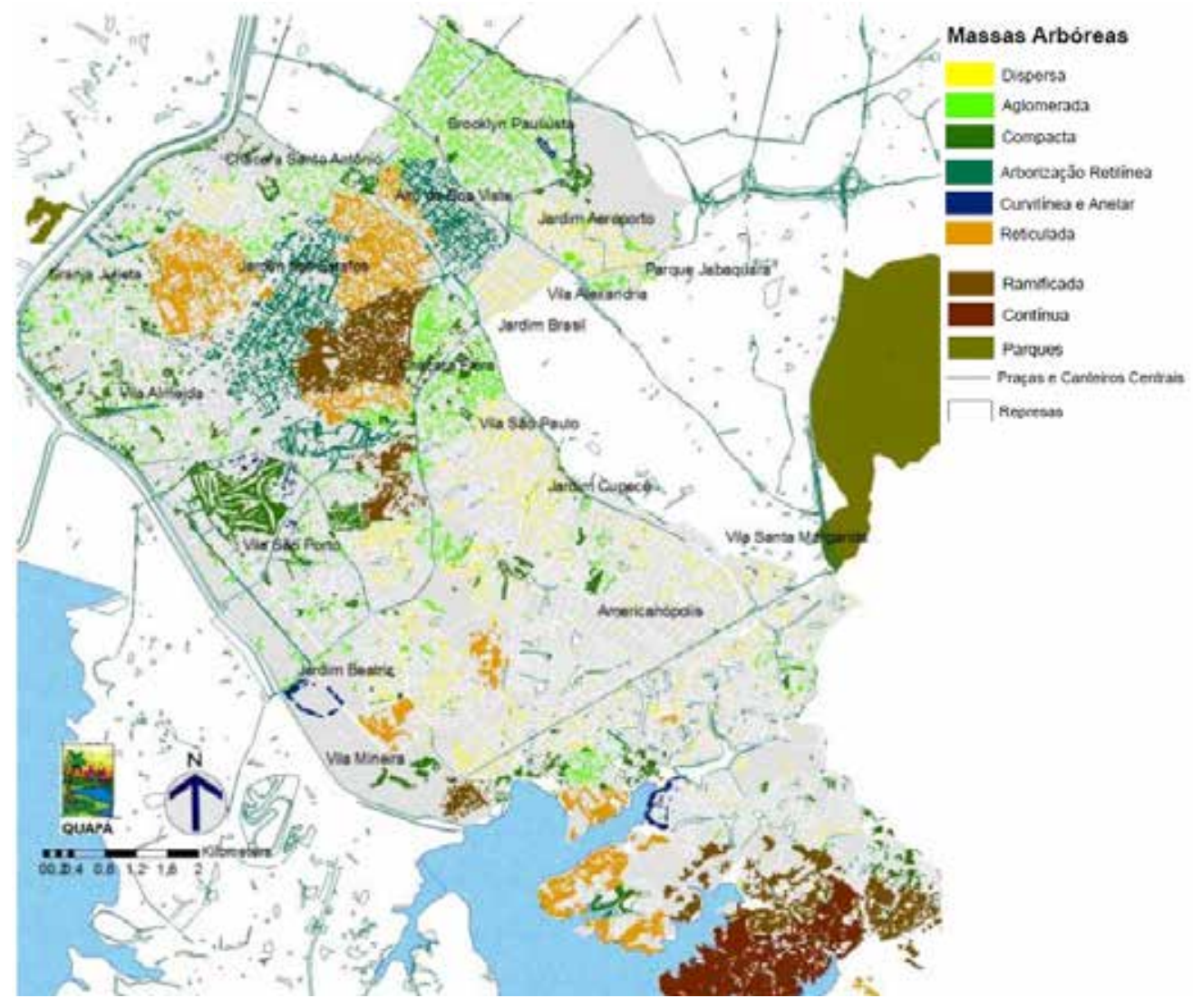

Figura 27 Classificação da vegetação de porte de acordo com os tipos propostos por Jim (1989).

Fonte: Acervo do autor, 2013.

Encontrou-se, entretanto, uma notável exceção: estas características são vistas na zona sul, próximo à marginal Pinheiros e às bordas da represa Billings, sem que exista uma quantidade significativa de árvores mapeadas. Tal incongruência é explicada pela tipologia construída (figura 30), que revela na região a existência de grandes estruturas - como galpões industriais - onde pouco interessou o plantio de árvores, já que, nos últimos anos, o verde tornou-se um elemento valorizado pelo mercado imobiliário. Corroborando esta ideia, nota-se uma correlação entre arborização e dois tecidos essencialmente residenciais de alta renda: 
a) condomínios residenciais verticais ou horizontais, como os da Vila Sofia, próximos de um dos pontos mais arborizados da área de estudo, onde funciona um campo de golfe privado;

b) regiões residenciais horizontais, com edificações isoladas ou semi-isoladas e muito espaço livre intralote, como na Chácara Flora, que, apesar de não ser um condomínio residencial horizontal stricto sensu, é fisicamente fechado, possuindo tal representação social e abrigando a maior mancha de vegetação mapeada.

Em diversos contextos, a tipologia construída - e não apenas a oferta de espaço - define o comportamento da vegetação de porte na cidade. A arborização é mais expressiva dentro dos lotes ocupados por casas isoladas (ou por condomínios residenciais) do que dentro dos lotes ocupados por casas geminadas. Estes últimos tendem a ser pequenos e possuir frações permeáveis irrisórias para fins paisagísticos. Entretanto, lotes verticalizados, mesmo sendo médios ou grandes, são menos arborizados do que outros dotados de iguais dimensões e ocupados por casas isoladas ou condomínios residenciais.

O porquê disto é explicado pela inexistência de especificações legais que exijam o agrupamento do percentual de solo permeável em um único quadrante, havendo, também, no caso de prédios altos, a exigência de isolamento da edificação. Sobrepor a porção permeável ao longo das faixas de recuo torna-se uma forma de maximizar a área aproveitada pelo equipamento condominial. Desta forma, enquanto a torre é centralizada no lote, a área permeável é frequentemente disposta às margens do mesmo, formando uma pequena fresta perimetral de solo descoberto onde o plantio de árvores de médio ou grande porte é impossível. Tal situação não responde pela totalidade dos projetos na cidade ou área de estudo. Alguns apresentam áreas permeáveis contínuas e plantio de árvores.

A cobertura vegetal fora do lote, isto é, no espaço público, praticamente inexiste em bairros de baixa renda e pode existir em bairros de média e alta renda mesmo quando o espaço é insuficiente para o plantio. Calçadas estreitas foram regra em toda a área de estudo - tanto em bairros de baixa, quanto de média e alta renda - e a arborização, quando existente, impede uma circulação mínima. No Alto da Boa Vista, por exemplo, as calçadas definitivamente não cumprem a função urbana de circulação, mas, sim, servem de espaço, muitas vezes quase que exclusivo, para abrigar árvores.

Embora a Subprefeitura de Santo Amaro seja amplamente arborizada, trata-se de uma distribuição heterogênea de manchas agrupadas, ocasionalmente compactas (evidenciando que não se trata apenas de arborização viária), mas sempre desconectadas. Ainda que a inexistência de árvores em bairros de baixa renda demonstre a falta de compromisso do poder público com as camadas mais pobres da sociedade, a ausência de espaço na cidade compromete, a princípio, qualquer intenção de arborização que não seja intralote ou não esteja contida em parques, praças e canteiros centrais de avenidas mais largas.

Com as atuais condições urbanas, uma ampliação significativa da cobertura vegetal de São Paulo revela-se utópica. Entretanto, soluções paisagísticas - como 
parques lineares - podem prover o espaço que as calçadas (por limitações físicas) e os lotes não poderiam (por questões físicas, no caso dos menores, e legais, no caso dos maiores).

Parques lineares exigem espaços adequados para sua implantação. Estes espaços são encontrados na cidade de São Paulo, inclusive na área de estudo, destacando-se, entre eles, as antigas zonas industriais com galpões abandonados. São também usados em projetos de requalificação urbana, especialmente para áreas populares próximas a mananciais. Neste caso, a arborização passa a existir também próxima a áreas populares e com pouco espaço livre, as mais carentes, dentre todas, de qualidade ambiental.

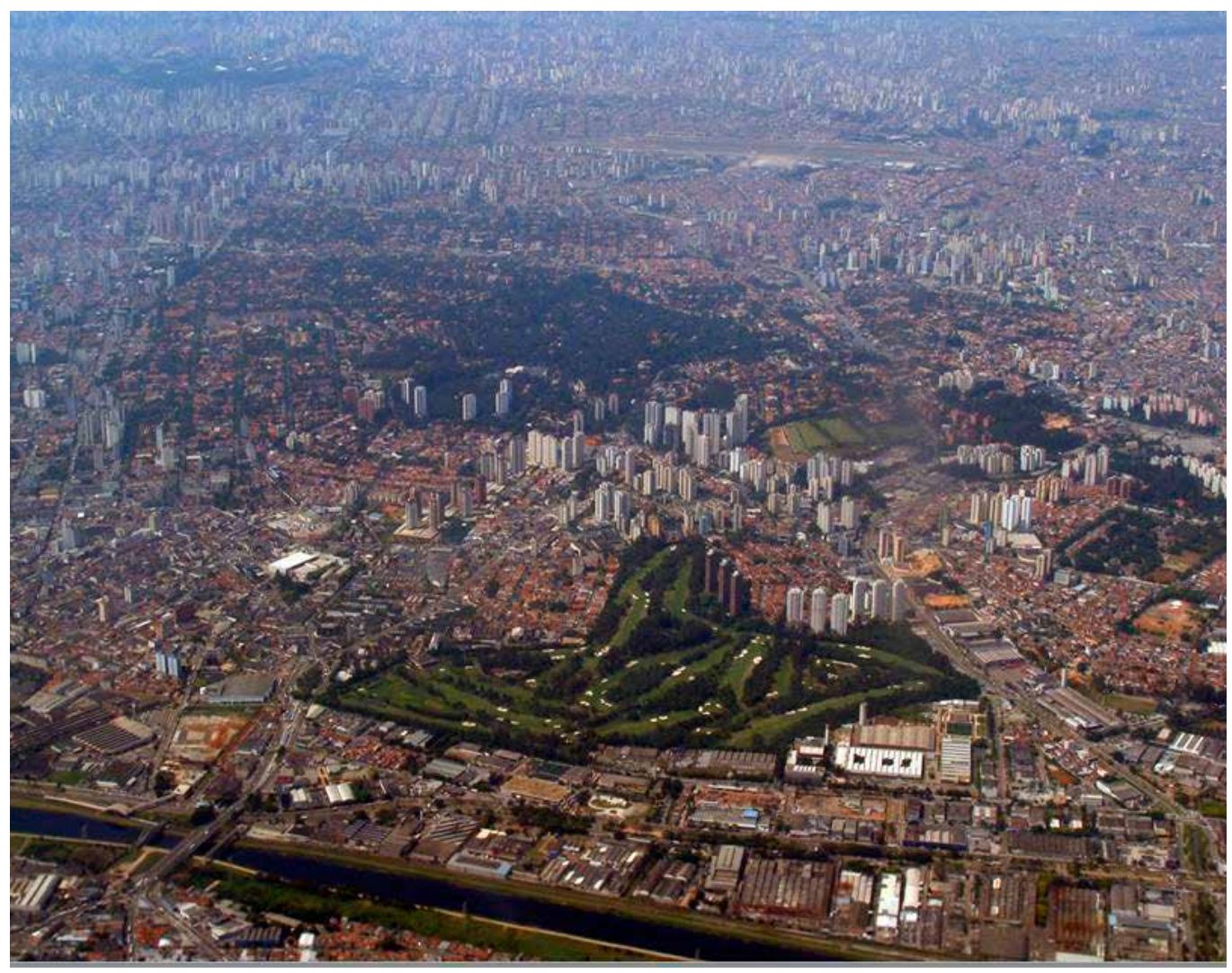

Figura 28 Foto aérea da área mapeada. Fonte: Acervo QUAPÁ, 2010. 


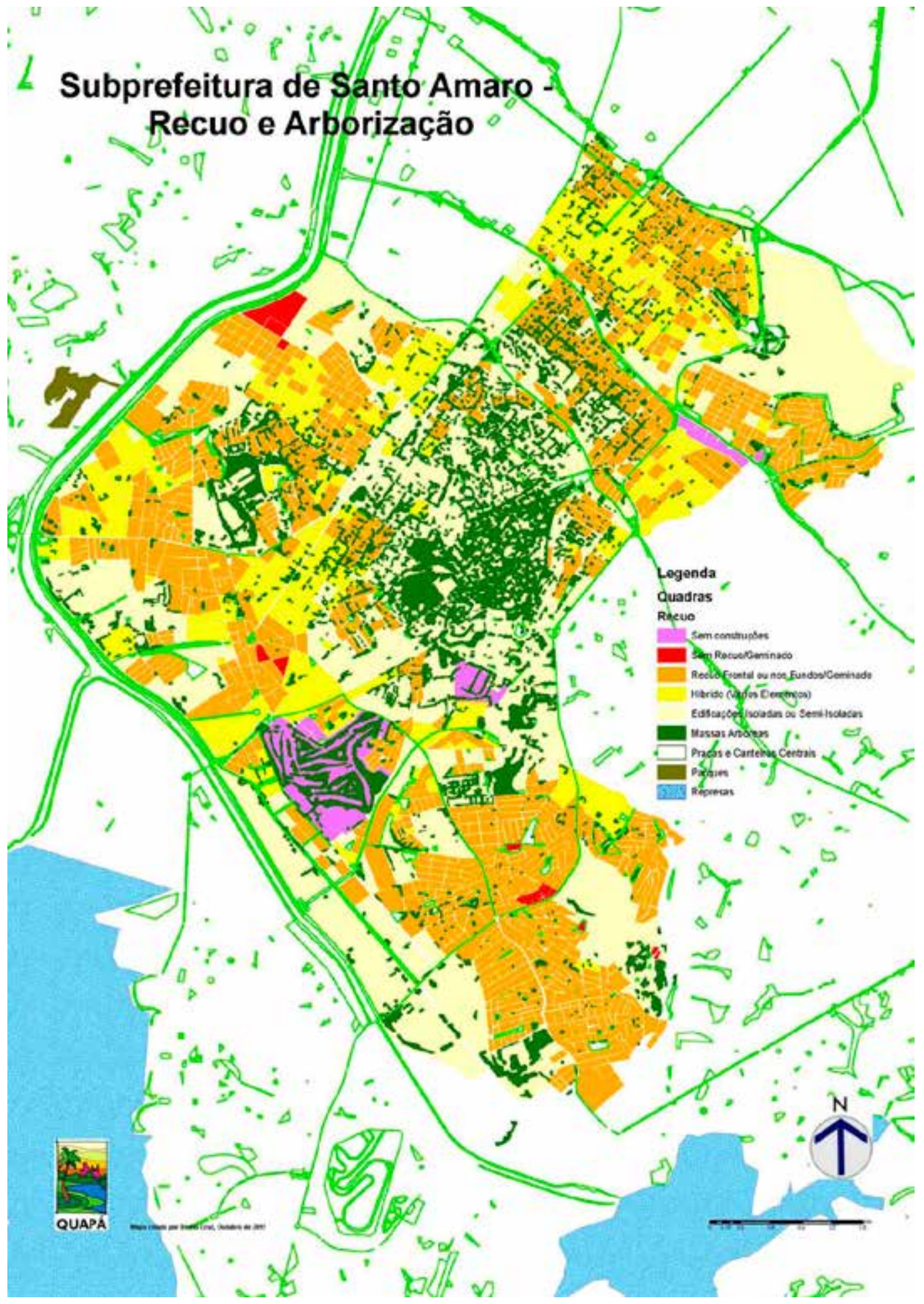

Figura 29 Recuos e arborização na Subprefeitura de Santo Amaro. Fonte: Acervo do autor, 2011. 


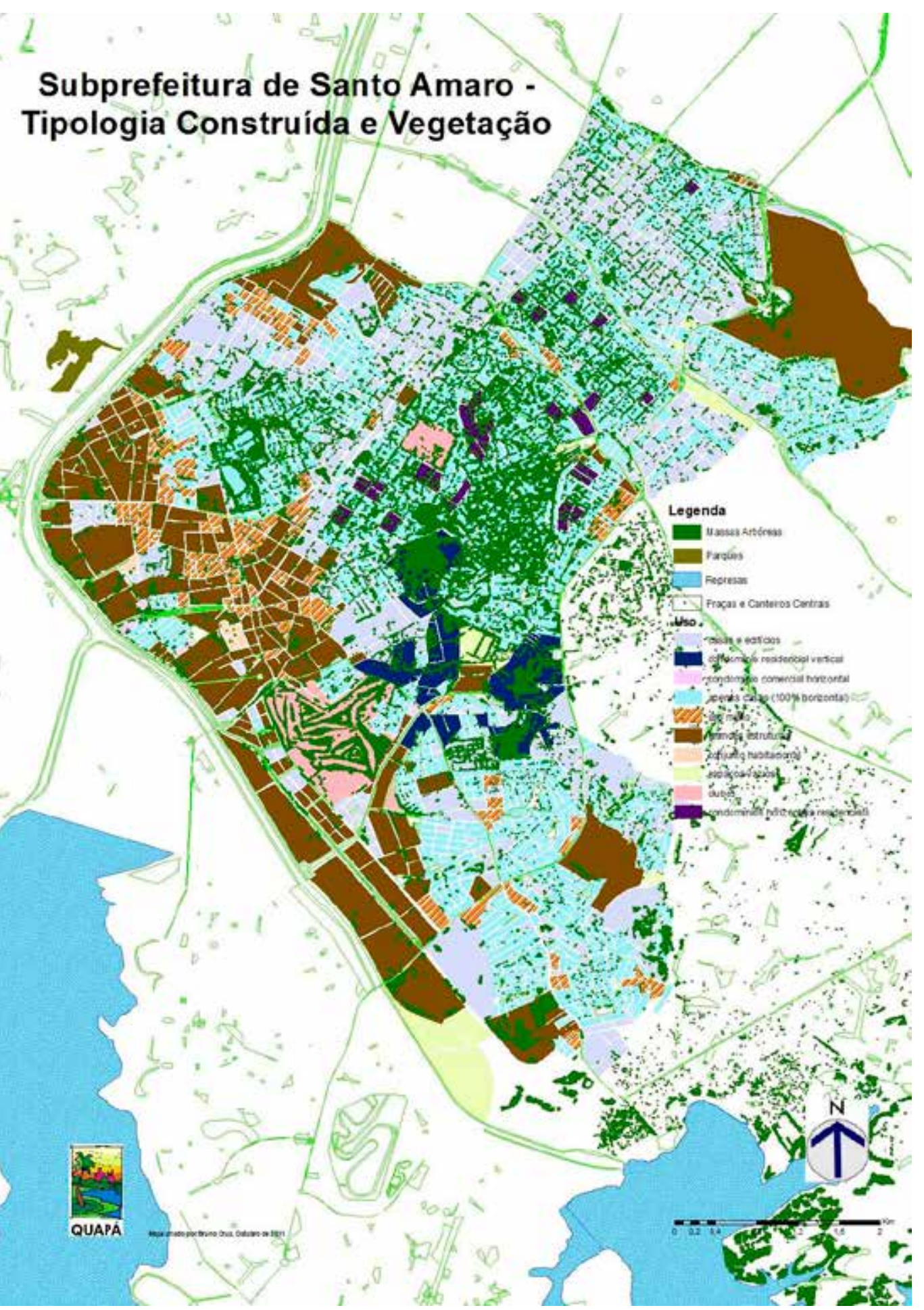

Figura 30 Tipologia construída e vegetação na Subprefeitura de Santo Amaro. Fonte: Acervo do autor, 2011. 


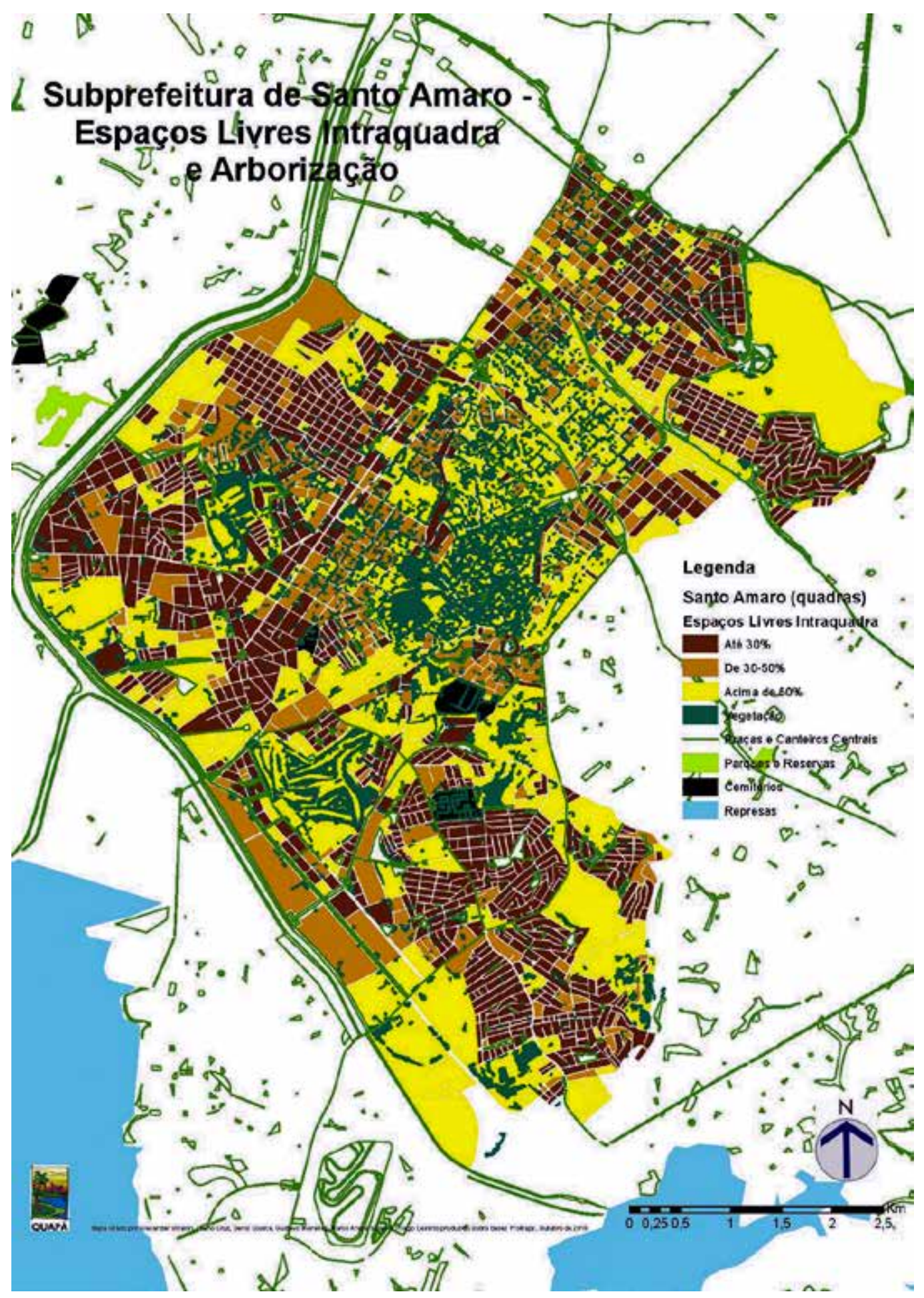

Figura 31 Subprefeitura de Santo Amaro, espaços livres intraquadra e arborização. Fonte: Acervo do autor, 2012. 


\section{REFERÊNCIAS BIBLIOGRÁFICAS}

ABBUD, Benedito. 1986. 209 f. O uso da vegetação no paisagismo. Dissertação (Mestrado em Paisagismo) Faculdade de Arquitetura e Urbanismo da Universidade de São Paulo, São Paulo, 1986.

ABRAMSON, Arne. Revitalizing Streets. In: FELLOWES, L. (Org.). Urban open spaces. London: Cooper-Hewitt Museum/Academy Editions, 1981, p. 82.

AKBARI Hashem. Cooling our communities: a guidebook to tree planting and light colored surfacing. U.S. E.P.A., Office of Policy Analysis. Environmental Protection Agency. Climate Change Division, Lawrence Berkeley Laboratory, Washington United States. Dept. of Energy, 1992.

ANDERSON, L.M.; CORDELL, H.K. Influence of trees on residential property values in Athens, Georgia (USA): A survey based on actual sales prices. Landscape and Urban Planning - LANDSCAPE URBAN PLAN 01/1988; 15:153-164. 1988.

ANSI/ASHRAE Standard 55. Disponível em: <https://www.ashrae.org/resources--publications/bookstore/ standard-55>. Acesso em: 19 ago. 2011.

FEDERER, C. A. Effect of trees in modifying urban microclimate. Little and JH Noyes. University of Massachusetts, Boston, 1971.

FORMAN, Richard; OLSON, James; DRAMSTAD, Wenche. Landscape ecology principles in landscape architecture and land-use planning. Washington: DC Island Press: Harvard University, 1996.

FURLAN, Sueli. Paisagens sustentáveis: São Paulo e sua cobertura vegetal. In: CARLOS, Ana Fani Alessandri; OLIVEIRA, Ariovaldo Umbelino de; DROULERS, Martine; ARROYO, Mónica; FERREIRA, Rosely Pacheco Dias; MANFREDINI, Sidneide (Orgs.). Geografias de São Paulo: a metrópole do século XXI. São Paulo: Contexto, 2004.

GREY, Gene W. The urban forest. 2th ed. Michigan: John Wiley \& Sons, 1978.

INMET. Disponível em: <http://www.inmet.gov.br/html/clima/conforto_term/index.html>. Acesso em: 19 ago. 2011.

JIM, Chi Yung. Tree-canopy caracteristics and urban development in Hong-Kong. In: Geografical Review. Hong Kong, v. 79, n. 2. American Geographical Society, 1989, p. 210-295.

LAURIE, Michel. Clima y microclima. Barcelona: Gustavi Gili, 1983.

LIMA, Ana Maria Liner Pereira. et al. Problemas de utilização na conceituação de termos como espaços livres, áreas verdes e correlatos. In: II Congresso Brasileiro de Arborização Urbana. Anais... São Luís: Imprensa EMATER/ MA, 1994, p.539-553.

LLARDENT, Luis Rodriguez A. Zonas verdes y espaços livres en la ciudad. Madrid: Closas Orcoyen, 1982.

MACEDO, Silvio Soares. 1987. 207 f. São Paulo, paisagem e habitação verticalizada: conflitos e padrões urbanísticos. Tese (Doutorado em Arquitetura e Urbanismo) - Faculdade de Arquitetura e Urbanismo da Universidade de São Paulo, São Paulo, 1987.

Paisagem, urbanização e litoral do éden à cidade. 1993. 189 f. Tese (Livre-docência) - Faculdade de Arquitetura e Urbanismo da Universidade de São Paulo, São Paulo, 1993.

Espaços Livres. In: Paisagem e ambiente: ensaios. n. 7. São Paulo: Faculdade de Arquitetura e Urbanismo da Universidade de São Paulo, 1995, p. 8 - 16.

MAGNOLI, Miranda Martinelli. Em busca de 'outros' espaços livres de edificação. In: Paisagem e Ambiente: ensaios, n. 21. São Paulo: Faculdade de Arquitetura e Urbanismo da Universidade de São Paulo, 2006, p. 17-30.

MASCARÓ, Luícia; MASCARÓ, Juan Luis. Vegetação urbana. Porto Alegre: Editora +4, 2010.

MENNEH, Márcia Halluli. Morfologia da paisagem verticalizada: conflitos e padrões urbanísticos. 1997. 282 f. Tese (Mestrado em Morfologia Urbana) - Faculdade de Arquitetura e Urbanismo da Universidade de São Paulo, São Paulo, 1997.

NBR 6401 (1980). Disponível em: <http://www.ebah.com.br/content/ABAAAACHkAE/nbr-6401-nb-10-instalacoescentrais-ar-condicionado-conforto-parametros-basicos-projeto >. Acesso em: 19 ago. 2011.

NBR 9050 (2004). Disponível em: <http://www.pessoacomdeficiencia.gov.br/app/sites/default/files/ arquivos/\%5Bfield_generico_imagens-filefield-description\%5D_24.pdf>. Acesso em: 19 ago. 2011.

PARKER, J. R. The impact of vegetation on air conditioning consumption: controlling summer heat island. In: AKBARI Hashem; GARBESI Karina; MARTIEN, Phil. (Eds.). Proceedings of the workshop on: saving energy and reducing atmospheric pollution by controlling summer heat island. University of California, Barkley, California, 1989, p. 42-52. 
PLANO DIRETOR ESTRATÉGICO DO MUNICÍPIO DE SÃO PAULO, Lei nº 13.430 de 13 de setembro de 2002 (Projeto de Lei n 290/02, do Executivo): Disponível em: <http://ww2.prefeitura.sp.gov.br/secretarias/ desenvolvimentourbano/plano_diretor/integra/formato_do_arquivo.pdf > . Acessado pela primeira vez em: jan. 2010.

PREAMBE. Home Page Unilivre, 2001. Meio digital. www.unilivre.org.br.

PREFEITURA MUNICIPAL DE SÃO PAULO, Decreto n 45.904, de 19 de maio de 2005. Regulamenta o artigo $6^{\circ}$ da Lei n. ${ }^{\circ}$ 13.885, de 25 de agosto de 2004, no que se refere à padronização dos passeios públicos do município de São Paulo.

ROBINETTE, Gary. Plants, people and environmental quality: a study of plants and their environmental functions. U.S. Dept. of the Interior, National Park Service; [for sale by the Supt. of Docs., U.S. Govt. Print. Off.] (1972). National Park Service, 1972.

SECRETARIA DO Verde E DO MEIO AMBIENTE. Manual técnico de arborização. São Paulo: Prefeitura de São Paulo, 2005.

SHINZATO, Paula. 2009. 210 f. Impacto da vegetação nos microclimas urbanos. Dissertação (Mestrado em Arquitetura e Urbanismo) - Faculdade de Arquitetura e Urbanismo da Universidade de São Paulo, São Paulo, 2009.

SILVA, Rooseman de Oliveira. O lugar do espaço público na paisagem pós-moderna. In: ENCONTRO NACIONAL DO ENSINO DE PAISAGISMO EM ESCOLAS DE ARQUITETURA E URBANISMO NO BRASIL, 7, 2004, Belo Horizonte. Anais... Belo Horizonte: Escola de Arquitetura e Urbanismo da UFMG. Disponível em: <http://www.usp. br/fau/depprojeto/gdpa/paisagens/encarte 1.html>. Acesso em: 2 out. 2012.

TAHA, Haider G.; AKBARI Hashem; ROSENFELD, Arthur H. Vegetation canopy micro-climate: a field project in Davis, California. Lawrence Berkley in Davis, Laboratory Report-24593, Berkley, CA (1988). Theor Appl. Climatol., 44 , p. 123-138, 1991.

TUNNARD, Cristopher; PUSHKAREV, Boris. Man-made America: chaos or control? An inquiry into selected problems of design in the urbanized landscape. 5th ed. Yale University Press, New Haven, 1963.

VOOGT, James A. Urban heat islands: hotter cities. 2004. Disponível em: <http://www.actionscience.org/ environment/voogt.html>. Acesso em: 2012.

WILSON, Edward. Biophilia. Harvard University Press, Washington DC., 1984.

YÁGIZI, Eduardo. O mundo das calçadas: por uma política democrática de espaços públicos. São Paulo: Humanitas, FFLCH-USP, 2000. 
